NBER WORKING PAPER SERIES

\title{
WHO PAID LOS ANGELES' MINIMUM WAGE? A SIDE-BY-SIDE MINIMUM WAGE EXPERIMENT IN LOS ANGELES COUNTY
}

\author{
Christopher Esposito \\ Edward E. Leamer \\ Jerry Nickelsburg \\ Working Paper 28966 \\ http://www.nber.org/papers/w28966 \\ NATIONAL BUREAU OF ECONOMIC RESEARCH \\ 1050 Massachusetts Avenue \\ Cambridge, MA 02138 \\ June 2021
}

This research was funded by a grant from the Laura and John Arnold Foundation. The views expressed herein are those of the authors and do not necessarily reflect the views of the National Bureau of Economic Research.

NBER working papers are circulated for discussion and comment purposes. They have not been peer-reviewed or been subject to the review by the NBER Board of Directors that accompanies official NBER publications.

(C) 2021 by Christopher Esposito, Edward E. Leamer, and Jerry Nickelsburg. All rights reserved. Short sections of text, not to exceed two paragraphs, may be quoted without explicit permission provided that full credit, including $(\odot$ notice, is given to the source. 
Who Paid Los Angeles' Minimum Wage? A Side-by-Side Minimum Wage Experiment in Los Angeles County

Christopher Esposito, Edward E. Leamer, and Jerry Nickelsburg

NBER Working Paper No. 28966

June 2021

JEL No. J2,J3,J31

\begin{abstract}
$\underline{\text { ABSTRACT }}$
In the restaurant industry, the incidence of an increase in the minimum wage may fall on restaurant owners, customers, landlords, and/or employees. We analyze the first two in this study, with implications for the incidence borne by landlords and employees. We exploit a geographical discontinuity in Los Angeles County, where in 2015 the City of Los Angeles passed a minimum wage law and in 2016 the State of California passed a different minimum wage law. This created two minimum wage schedules in the county that remained unequal for over five years. Using a novel data set from a multi-year price survey, our analysis shows that the incidence of Los Angeles City's higher minimum wage fell on customers in high-income neighborhoods, and on landlords and restaurant owners in low-income neighborhoods. We further show that the mix of responses at restaurants subject to the LA City minimum wage, including price increases, menu changes, and restaurant closures, was affected by proximity to restaurants subject to the lower California State minimum wage. The effect of neighborhood income levels and distance to lowerwage competition has important implications for designing minimum wage policies.

Christopher Esposito

Department of Sociology and

Mansueto Institute for Urban Innovation

University of Chicago

Chicago, IL 60637

Jerry Nickelsburg

John E. Anderson Graduate School of Management University of California, Los Angeles

Los Angeles, CA 90095

jerry.nickelsburg@anderson.ucla.edu
\end{abstract}

cresposito@ucla.edu

Edward E. Leamer

John E. Anderson Graduate School of Management

University of California, Los Angeles

Box 951481

Los Angeles, CA 90095-1481

and NBER

edward.leamer@anderson.ucla.edu 


\section{Introduction: The Minimum Wage in Los Angeles County}

In the summer of 2015, the City of Los Angeles enacted a schedule of minimum wage increases that would reach \$15/hour in July 2020. Los Angeles County, which encompasses the City of Los Angeles, is comprised of 88 governmental jurisdictions not legally subject to the City's minimum wage ordinance. In 2016 California enacted a statewide schedule of minimum wage increases which set a minimum for all 89 jurisdictions. The California state schedule of increases differed from the City's in three important ways. First the California state minimum wage would not reach $\$ 15 /$ hour until January 2022. Second, the two minimum wages are indexed to the CPI, but the indexation starts earlier for the City's minimum wage. Third, in a recession, the Governor of California can suspend increases in the state minimum wage thereby extending the lower wage longer, while the City's wage has no such provision. Absent the latter two differences, the minimum wage in Los Angeles City and in a handful of jurisdictions within Los Angeles County that elected to follow the City's minimum wage schedule will be $\$ 1$ to $\$ 1.50$ /hour higher than in the rest of the County between July 2017 and January 2022 (Figure 1).

Figure 1: Minimum Wage Schedules for Businesses with 25+ Employees in Los Angeles

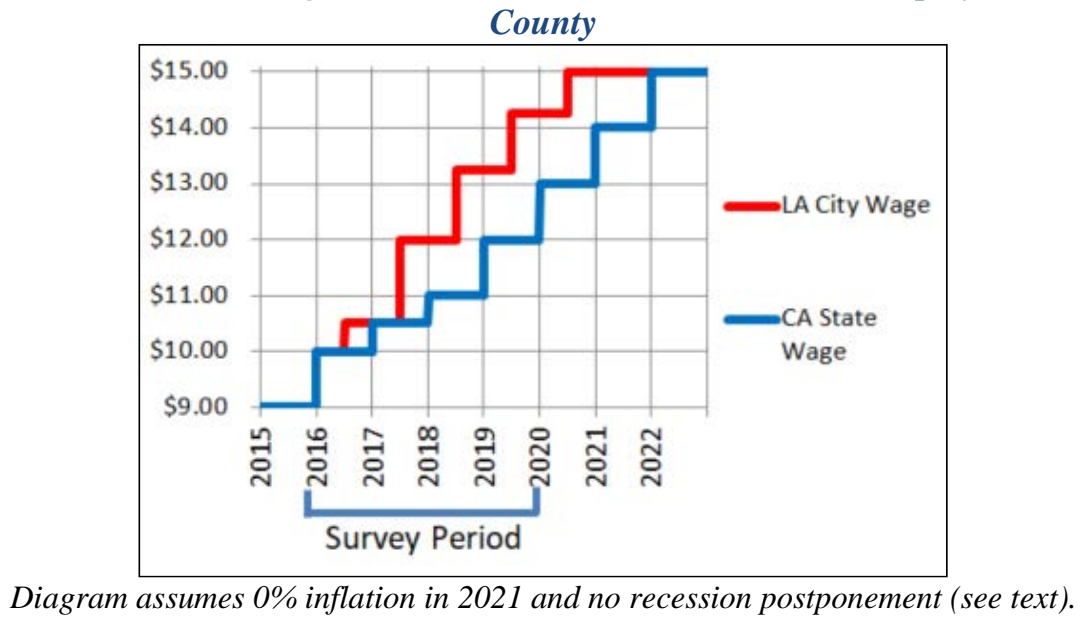

The City Wage and State Wage levels could ultimately converge, but they would not do so for a minimum of six years. Since the minimum wage schedules are set by statute, employers are facing the entire future wage schedules. Though the minimum wage schedules dictate a sequence of wage effects over time for minimum wage workers, the timing of wage changes for other workers and also price responses and employment responses reflect complicated mixtures of anticipatory responses and postponements. Thus, in this article we emphasize the cross-regional variability in price changes over the whole entire period.

After this introductory section (1), there are three sections linking this study: section (2) to the literature on minimum wages, section (3) to the QCEW data on average wages and employment in Los Angeles, and section (4) to a geographic market theory of wages across borders. Section (5) describes a price survey of restaurants that we conducted across the County of Los Angeles over a four-year period. An analysis of summary statistics and regression results are presented in Sections (6) and (7). The results from the price data leave open several questions which are addressed in Sections (8) and (9) by an analysis of menu item changes and restaurant closures at the same set of restaurants in the price survey. Combining spatial economic heterogeneity across the county, the minimum wage discontinuity at the minimum wage borders, and the unique data set from the four-year survey generates insight as to the incidence of the minimum wage differential and reconciles core disagreements in the existing minimum wage literature. 
The analysis is structured to contrast survey responses from State Wage restaurants located far from City Wage competition (State Non-Border restaurants) with three other sets of restaurants: State Wage restaurants located near City Wage competition (State Border restaurants), City Wage restaurants located near State Wage competition (City Border restaurants), and City Wage restaurants located far from State Wage competition (City Non-Border restaurants). Using this $2 \times 2$ stratification of a unique data set generated through four-years of surveys of restaurant menus, we are able to ask three central questions: (a) are the City and State minimum wages schedules different enough to manifest a difference in restaurant prices, (b) are price increases affected by proximity to competitors subject to higher or lower minimum wages, and (c) is there evidence as to whom the incidence of the minimum wage might have fallen if not customers through higher prices?

In addition to customers, the incidence of a minimum wage may fall on restaurant owners through diminished returns to capital including the restaurant brand, on labor through reduced hours or changes in working conditions, or on property owners through a reduction in land rents and returns to capital improvements on restaurant properties. Using our unique stratified random sample of Los Angeles County restaurants, we show that price increases account for the full incidence of the City minimum wage differential at restaurants in high-income neighborhoods located at least one mile from State wage competition. Closer to the wage-border, restaurants in high-income neighborhoods did not raise prices, were more likely to change their menus, and were more likely to close. For those that stayed open, at least part of the incidence fell on restaurant owners through lower margins. For those that closed, we infer that the owners bore some of the incidence through loss of investment in human capital and branding, and that the remainder of the incidence was borne by landlords through lower land rents.

The theory that we present in Section (4) assumes an equilibrium in the labor market with workers near the minimum wage border indifferent between the high-wage and the low-wage opportunities. This indifference is created by a higher level of effort required for the higher wage opportunity, which could mean staggered hours and faster pace during work hours. This kind of productivity response to an increase in the minimum wage is commonly referred to in the literature but we do not have any productivity data to study.

In our study, we control for neighborhood income levels because customers prefer restaurants close to where they live, and because residents of high-income neighborhoods may have relatively inelastic demand for restaurant meals. Thus, restaurant owners in these neighborhoods should, on average, be able to pass along additional wage costs to their customers without a reduction in sales. Tellingly, in low-income neighborhoods we find that restaurants subject to the City Wage did not have statistically significant price increase for existing menu items, but they did change menu items more often. Finally, we note that small mom-and-pop restaurants are only subject to minimum wage requirements on statutory employees. Family members working at the restaurant are not considered employees. Momand-pop restaurants are more concentrated in low-income neighborhoods, and this might also help to explain the lack of price increases in these regions.

\section{Linkage to the existing literature}

Our findings that restaurants pass at least part of minimum wage increases on to restaurant customers and landlords are consistent with the growing literature that finds that modest minimum wage increases result in little to no loss in overall employment (Card and Kruger 1994, Aronson 2001, Neumark and Wascher 2008, Lemos 2008, Dube, Lester and Reich 2010, Harasztosi and Linder 2017). Card and Kruger (1994) studied limited-service restaurants in Pennsylvania and New Jersey after the latter increased its minimum wage. They found no decrease in employment in New Jersey, but an increase in prices. The restaurants in their treatment area were dispersed across New Jersey and included restaurants close to and far away from the border. Other studies such as Aaronson et al 
(2008) using composite meal prices from the Bureau of Labor Statistics CPI survey find similar price increases and output responses, and they infer from that, geographical differences in market structure.

Our study is in a similar vein but with the following differences that bring new insights to this topic. First, our geographical scale of analysis, Los Angeles County, is a single labor market within which restaurant demand and many of the factors affecting restaurant prices such as the cost of restaurant real estate should move similarly across the entire region. Second, we explicitly study competition across the minimum wage border. Third, we administer our survey for a longer period of time allowing for greater adjustment on the part of restaurant owners. Fourth, we study a larger minimum wage increase, with the Los Angeles City wage rising from $\$ 9.00 /$ hour to $\$ 14.25 /$ hour during our study. Fifth and finally, we decompose our results based on neighborhood average household income levels.

More detailed studies of the purchase of food away from home by Lee and Brown (1986), McCracken and Brandt (1987), Byrne, Capps and Saha (1996), and Richards and Mancino (2013) all found the price elasticity of demand for limited-service restaurants to be relatively inelastic at the industry level. Frick, Gergaud, and Saulais (2015) found a similar elasticity for food away from home demand at the industry level in six European countries based on two surveys taken 18 months apart. These studies were on frequency of visits and on total food expenditure per visit, and not the prices of the restaurant items and not for an individual restaurant but at the aggregate industry level. Though useful, they did not account for changes in the composition of food purchased on the part of the consumer, nor on changes in menu items in response to the demand shift on the part of the restaurant.

Restaurant demand elasticities have been explored in the health care literature to ascertain the efficacy of using the price system to encourage healthier eating. Adreyeva, Long and Brownell (2017) provide a good survey of this literature. The consistent finding is that soft drink purchases are responsive to price signals. The exception is a study by Kahn, Powell and Wada (2012) that examined limitedservice restaurants with a sample of fast food chains to ascertain the elasticity of demand for a visitation to fast food chain among middle school children. Though they found an elasticity of -.57 the study did not predict how much or what was purchased during a visitation. A limitation of their study is that they employed prices from a regional index of the cost of purchasing a meal at this class of restaurants rather than the actual prices faced by the children.

\section{Economic Environment: What the QCEW data tell us}

Minimum wage effects are likely to be different during expansions when business energy is focused on acquiring more customers versus recessions when the concern is concentrated on cost control. Because our collection of restaurant prices took place during a prolonged period of economic expansion in Los Angeles County, our findings are limited to that period. Figure 2 displays Los Angeles County total employment and overall wage rate from the QCEW database. These form the economic background within which minimum wages were increased during the period from 2016 to 2019 when both overall employment and wages were on the rise. The seasonality of average wages is quite strong with a peak in Q4. The employment peak is also in Q4, but the seasonal pattern is otherwise different. 
Figure 2: Los Angeles County Restaurant Employment and Average Weekly Wages

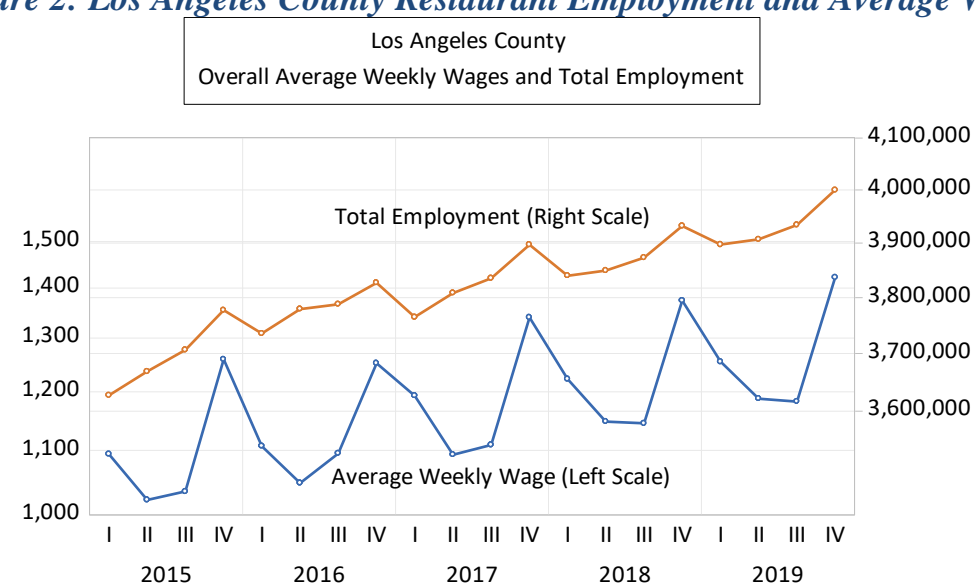

Figure 3 has the corresponding data for limited service and full-service restaurants, both of which experienced rising employment and they rise roughly in parallel with the overall data, though the seasonal effects are quite different. Figure 4 allows a direct comparison of the restaurant data with the overall data by illustrating employment and wage ratios. Here we see that that the full-service restaurant employment share rose slowly from 2015 to 2017 but then declined slowly. The employment share of limited-service restaurants was more clearly on the rise from 2015 to 2018 when it peaked. The wage ratio has a strong seasonal pattern, but both of the restaurant sectors experienced a rise which can be seen by tracking either the peaks or the valleys.

Figure 3: Los Angeles County Restaurant Employment and Average Weekly Wages

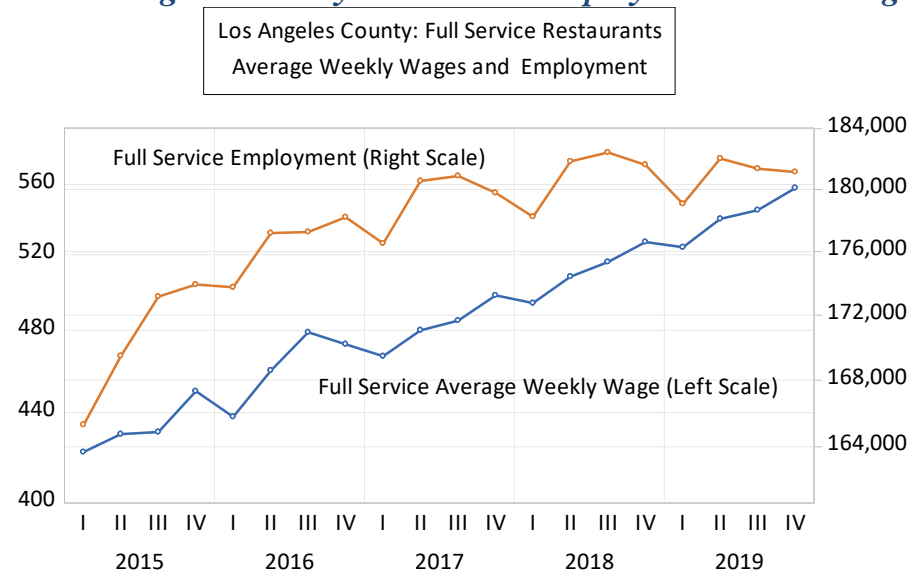




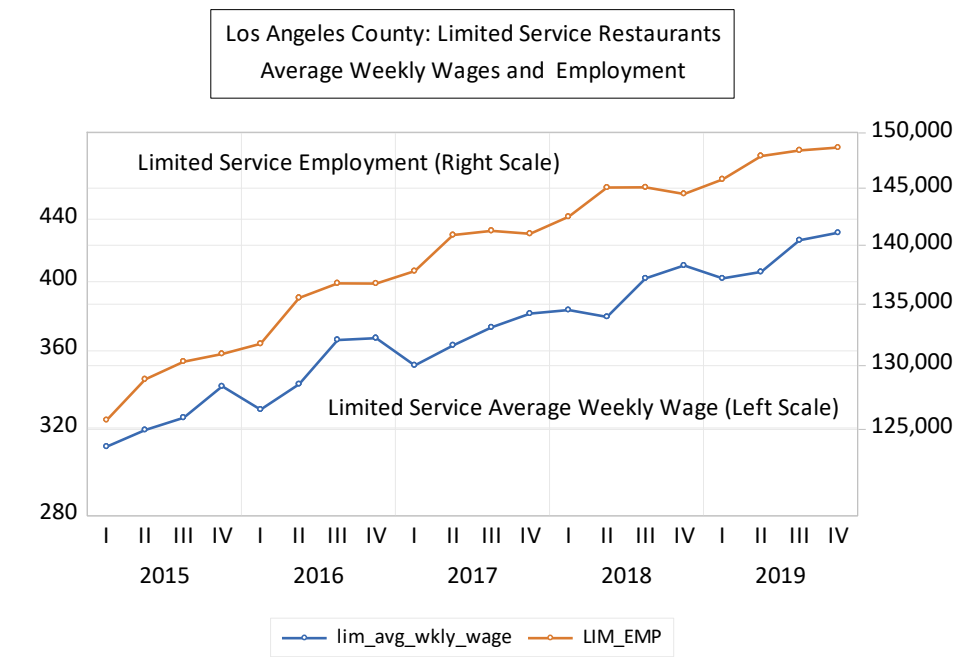

Figure 4: Los Angeles County Ratios

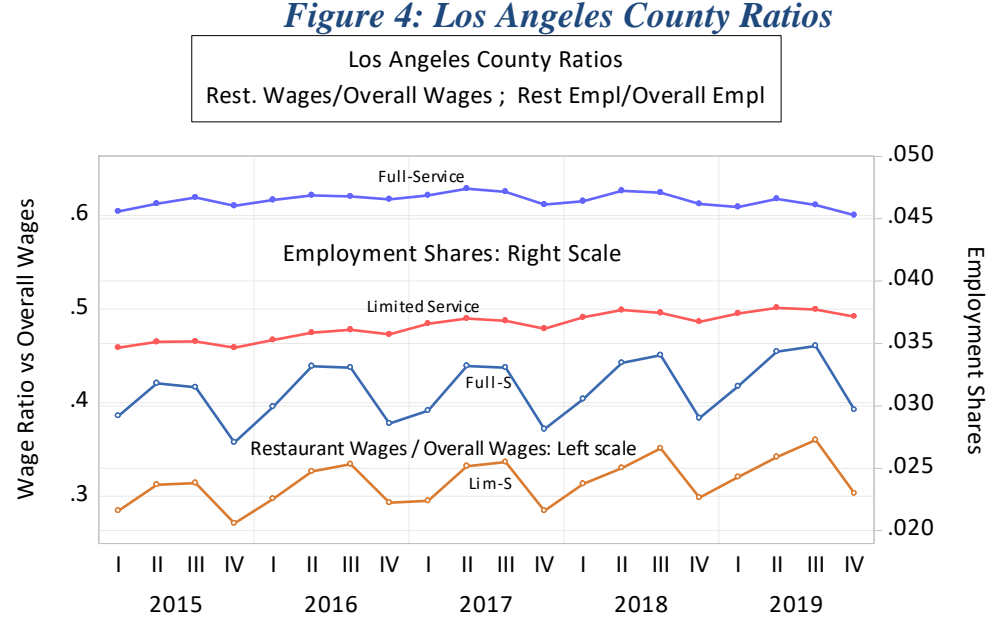

Table 1 has regressions that put the moving pieces in these figures together, explaining the log of restaurant employment and wages as a function of (1) a lagged dependent variable to account for the persistence of departures from normal, (2) the log of the California minimum wage, (3) the log of the overall employment or wages depending on which is the dependent variable, and (4) quarterly dummy variables that measure departures from QTR $=1$, which is the omitted effect absorbed by the constant C. An important problem with this regression is that much of the County is subject to the City minimum wage which generally exceeds the State minimum wage. This means there is an omitted variable equal to the City wage minus the State wage, which is pretty constant except for the fact that the City increment comes in July while the State increment comes in January. A second, and possibly more important problem, is that the minimum wage schedules are announced in advance, and the response of employment and wages need not be timed with the arrival of the pre-announced increases. The third, and most important problem, is that there is no control group without any minimum wage increases.

With those caveats, the regressions in Table 1 are quite interesting. Attention in this table is focused with shading green or red on the t-statistics greater than 2 or less than minus 2 . For the employment variables, the effect that is most statistically apparent is the lagged dependent variable (persistence). This persistence reinforces our view that the response of employment to a schedule of future minimum wage increases cannot be timed to the minimum wage increments but must take into account the future minimum wages. Employment in limited-service restaurants tracks overall employment in a statistically discernable way while employment in full service restaurants does not. For wages, the persistence effect is not detectable, but both the minimum wage and the overall LA 
County wage are statistically significant. It is worth mentioning that the minimum wage coefficients in both employment equations are negative, though not statistically significant. This could be summarized with the conclusion that effects on wages are apparent with this kind of regression model because the law requires actual wages to move with the minimum wages but the effects on employment are disguised by the fact that employment changes are not necessarily timed to the minimum increase: there can be adjustments in advance and adjustments long after.

Table 1: Regressions Explaining Los Angeles County Employment and Average Weekly wages in Full Service and Limited-Service Restaurants

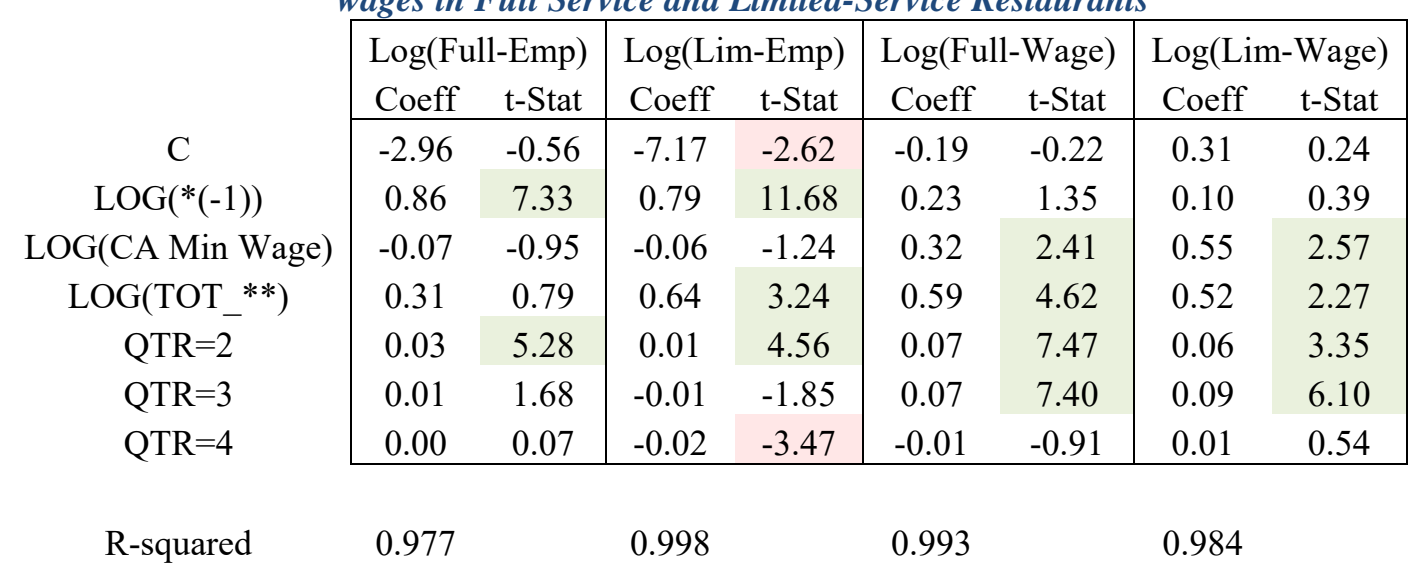

t-stats in excess of 2 in absolute value are highlighted

* refers to the dependent variable.

** refers to employment for the employment regressions and wages for the wage equation.

These results do conform with the minimum wage literature which finds apparent wage effects but often no apparent employment effects. This is natural segue into our study of restaurant prices: To what extent do LA county restaurants pass on the rising wages to customers via price increases, and to what extent to the City and State minimum wages produce different increments in prices?

\section{A Theory of Geographic Effects}

The border regions are of special interest because in a long-run equilibrium, two identical restaurants on different sides of the same street with different minimum wages cannot have materially different prices and cannot have materially different wages. (Yes, there are such streets in Los Angeles.) Restaurants on the high-wage side of the street can escape the high wage by moving to the other side, but landlords would offset that with lower rents. That's a step toward establishing a new equilibrium with production costs the same on each side of the street, but what about the wage difference? Who gets to decide which workers are paid the higher wage? To solve this problem, the private market would surely recognize that the wage is only one part of a complex labor contract that includes punctuality and intensity, captured by an "effort" variable per Leamer (1999). The restaurants on the high-wage side of the street can demand a level of effort that is high enough to make workers indifferent to the side of the street. That determines the across-the-street difference in effort level and leaves it to the overall supply of effort to determine the level. For example, suppose that there is migrant labor that comes from a region with wages not directly affected by the City and State minimum wage. To create an equilibrium with the marginal workers indifferent between all three locations, the effort level on the low-wage side has to also be increased. The minimum wage literature routinely celebrates this increase in productivity, but often ignores the fact that higher productivity comes with fewer jobs. (See Kim and Jang (2019) for a study of restaurant productivity). 
We can summarize this discussion with a zero-profit equation that sets the product price equal to the cost:

$$
p=\frac{w}{e}+r
$$

where $\mathrm{w}$ is the wage per hour, 1/e is hours of work per unit of output (e is effort) and $\mathrm{r}$ is the rental cost of the land per unit of output. (We are abstracting from investments such as the structure and equipment.) We can assume that prior to the increase in the minimum wages both sides of the street had the same $\mathrm{p}, \mathrm{w}, \mathrm{e}$ and $\mathrm{r}$. Differentiating this equation sets the change in price equal to a function of the percentage increase in wages minus the percent change in productivity and the percent change in rents.

$$
\frac{d p}{p}=\frac{w}{p e}\left(\frac{d w}{w}-\frac{d e}{e}\right)+\frac{r}{p} \frac{d r}{r}=\theta\left(\frac{d w}{w}-\frac{d e}{e}\right)+(1-\theta) \frac{d r}{r},
$$

where $\theta$ is the labor share of value. Assuming that the increase in effort is not enough to offset the increase in wages, the wage effect on prices is positive. With this positive effect on the right hand side, for this equation to hold there must be a combination of positive price increases and negative rent increases. Applied separately on each side of the street, this equation calls for greater price increases on the high-wage side of the street and/or greater rental rate reductions also on the highwage side. But the greater price increases encourage customers to move from the high-side to the low-side until the prices are brought in line. This transfer of demand further lowers the rental rate on the high-wage side but increases the rental rate on the low-wage side. Our conclusion is the following: (1) the common price increase reflects a combination of the two different net wage increases $\theta\left(\frac{d w}{w}-\right.$ $\left.\frac{d e}{e}\right)$, (2) effort levels rise more on the high-wage side than the low-wage side, (3) rental rates fall on the high-wage side, but on the low-wage side rents fall less or even can increase as customers migrate across the street.

This discussion has assumed that all restaurants are located at the same point but in the real Los Angeles distance from the border insulates a restaurant from competition in the product market with restaurants on the other side of the border. A step toward the complex real two-dimensional geography of Los Angeles with hills and rivers and wiggly borders is a one-dimensional line of restaurants. This hypothetical helps think clearly about the changes in prices and rents near the border as opposed to far away. For the straight-line hypothetical, the image in Figure 5 contrasts the regions with State and with City minimum wages with the border in the center. On the State side, the minimum wage increased from $\$ 9$ in 2015 to $\$ 12$ in $2019,33 \%$. On the City side, the minimum wage increased from $\$ 9$ to $\$ 13.25$ in $2019,47.2 \%$. The two horizontal blue lines labelled dw/w near the top of the figure refer to these percentage increases. The two horizontal orange lines labelled de/e represent the hypothetical increases in effort that is induced by the minimum wage. This percentage increase is assumed to be $20 \%$ of the percent increase in minimum wages. With these minimum wage increases and corresponding effort increases, workers are assumed to be indifferent between the City and the State sides of the border and a third hypothetical region that has no minimum wage increment.

The red curve labelled "Neighborhood dw/w" is a weighted average of the wage changes within a mile of each restaurant with the highest weight at the location of the restaurant and with weights declining linearly to zero when locations are more than a mile away. Thus, restaurants a mile or more away from the border experience neighborhood average minimum wages that are equal to either the City or the State minimums, but within a mile of the border the neighborhood includes both minimum wages. This measure is meant to capture the competitive milieu without being explicit about consumer utility functions and costs of travel.

To create this image, we assume that the labor share $\theta$ is $50 \%$, and the pass-through of labor cost changes is $90 \%$ of the changes in neighborhood labor costs $\theta\left(\frac{d w}{w}-\frac{d e}{e}\right)$. The wage increase is greater 
on the City side but smoothly elevates from State to City side because of the neighborhood effects. Far from the border, the less than $100 \%$ pass-through requires a rental rate decline to keep restaurants with non-negative profits. Close to the border on the City side restaurants feel the competition from State restaurants with lower minimum wages and cannot pass all the incremental cost onto customers. That's where rents $\mathrm{dr} / \mathrm{r}$ fall to keep the restaurants from moving completely to the State side. This benefits restaurants close to the border on the State side, and because they experience price increases that exceed the increase in wage costs competition causes a rise in rents but farther in the interior the benefit of being close to the border disappears and rents must fall to help keep volume from falling too much.

Figure 5: Implications of a Restaurant Labor Market Model with Effort, Rents and Prices Variable

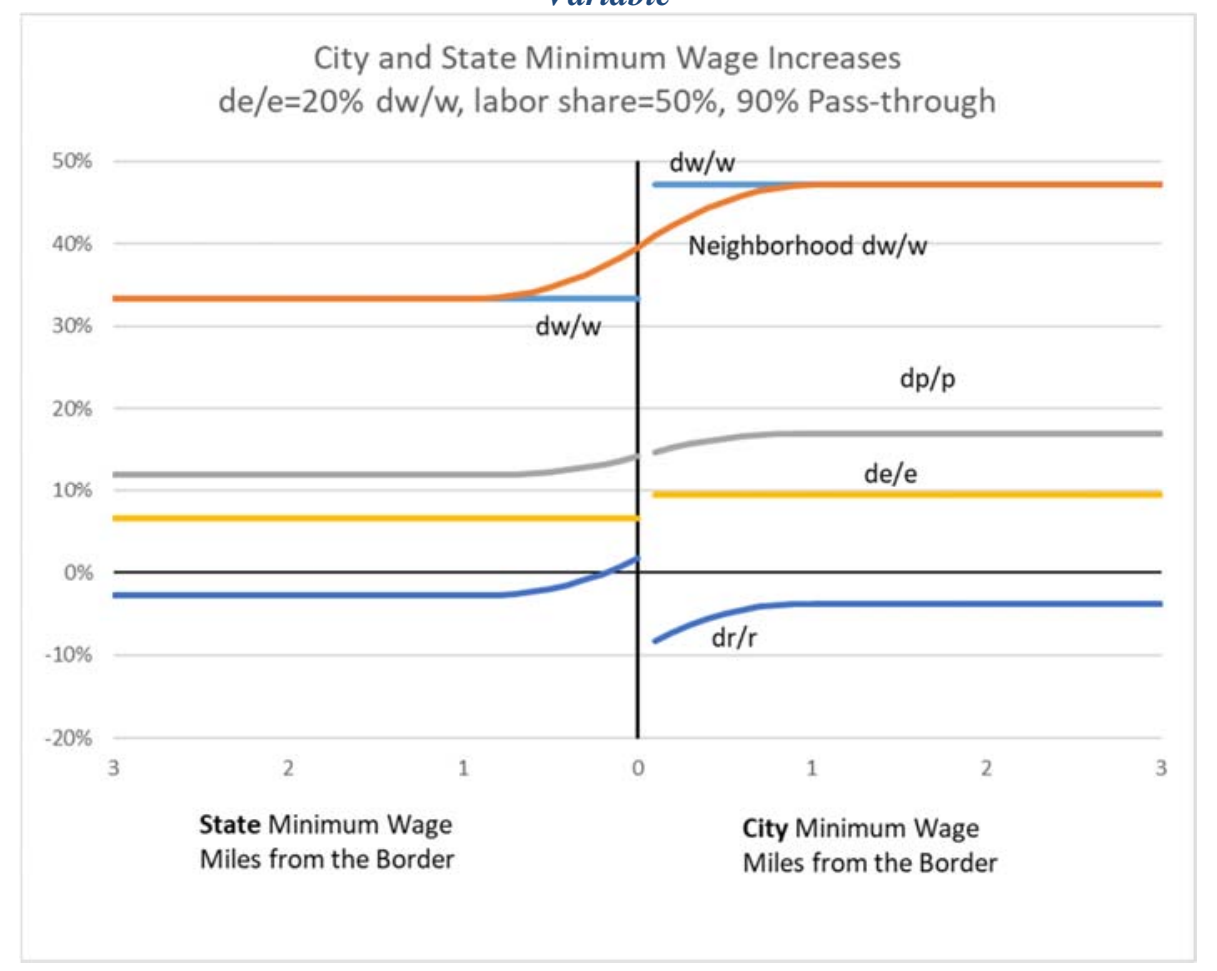

\section{Design of the Price Study}

Los Angeles County is the largest county in the United States and is comprised of 88 governmental jurisdictions and a population of over 10 million. In land area it is the $74^{\text {th }}$ largest county in the U.S. and is about one half the size of the state of New Jersey. Although Los Angeles City is the largest city in the county in demographic and geographical terms, its 4 million residents and 4.7 thousand square miles of land account for just $38 \%$ of the county's population and $10 \%$ of the county's total land area. The city has geopolitical holes within its perimeter. The cities of Beverly Hills, San Fernando, Santa Monica and West Hollywood are completely enclosed by the City of Los Angeles, as well as Culver City with an adjacent part of unincorporated LA County. In addition, there is a narrow corridor 0.5 miles wide and 5.14 miles long that connects the downtown to the port district. Sales taxes in Los Angeles County are set by the county and the state and do not vary across the study region.

When the City of Los Angeles enacted its schedule of minimum wage increases, the independent municipalities of Santa Monica and Malibu, as well as the Los Angeles County Supervisors (with jurisdiction over the unincorporated parts of the county) elected to adopt the same minimum wage schedule as the City. We refer to this minimum wage schedule as the City schedule and to its effective minimum wage as the City wage. The remaining municipalities in Los Angeles County, including 
Long Beach (population 469,000), Santa Clarita (population 210,000), and Glendale (population 203,000) did not adopt the City's minimum wage schedule. However, the California State minimum wage schedule, signed into law after the City's, has jurisdiction in all parts of the State that do not have a higher minimum wage in place. We refer to the statewide schedule of minimum wage increases as the State schedule and the effective statewide minimum wage as the State wage.

The minimum wage is due to be harmonized across the county in 2022 , however, there are several reasons why that is unlikely to come to pass. First, when each region reaches $\$ 15 /$ hour its minimum wage is indexed to the rate of inflation. The City Wage hits $\$ 15 /$ hour before the State Wage by $1 \frac{1}{2}$ years. If the rate of inflation were 3\%, then firms following the City Wage would have, absent a harmonization law, a minimum wage $4.5 \%$ higher than firms following the State Wage. Second, there is a provision in the State Wage law that allows California's governor to suspend increases in the minimum wage due to slack employment demand during recessions. There is no similar provision for Los Angeles City and other jurisdictions following the City Wage. While Governor Newsom did not invoke this deferment in January 2021, the possibility of invoking the deferment in addition to inflation is likely to cause firms subject to the City schedule to expect a higher minimum wage than firms following the State schedule beyond 2022.

For both minimum wage schedules, small firms ( $<25$ employees) can defer their wage increases by a year. Qualifying restaurants do not need to apply in order to receive this exemption. As it is difficult to ascertain which restaurants have fewer than 25 payroll employees (family members working in the restaurant do not count), we are unable to analyze the impact of this exception. When a numerical value for the minimum wage is required, we use the minimum wage of restaurants with 25 or more employees.

To study if restaurants passed the minimum wage increases on to their customers, we administered a survey of restaurant item prices in LA County. We took a random stratified sample $(n=800)$ of Los Angeles County-based restaurants from the Los Angeles County Department of Health inspections database and, with a team of UCLA undergraduate students, tracked the prices over time on up to 5 menu items at each restaurant. ${ }^{1}$ The survey was conducted biannually between November 2015 and December 2019. To ensure sufficient coverage, the sample selection was stratified by the minimum wage schedule applicable to the restaurant and by the straight line distance to the wage border. We defined border regions as those areas located within one linear mile from a part of the county subject to the alternative minimum wage. The strata nomenclature is: City Non-Border, City Border, State Border, and State Non-Border

In Figure 6, we color-code the four strata and pinpoint the restaurants in our sample. Two municipalities (Beverly Hills and West Hollywood) originally indicated that they would follow the City Wage but opted to follow the State Wage once it was passed by the state legislature. Because these two cities switched their intended wage schedule after we stratified our sample, the State Border stratum is overrepresented in our sample.

\footnotetext{
${ }^{1}$ The Los Angeles County Department of Public Health performs restaurant health inspections at all licensed restaurants in Los Angeles County, with the exception of those in the cities of Pasadena and Long Beach because they have their own health departments. Therefore, those two cities are not in our sample.
} 


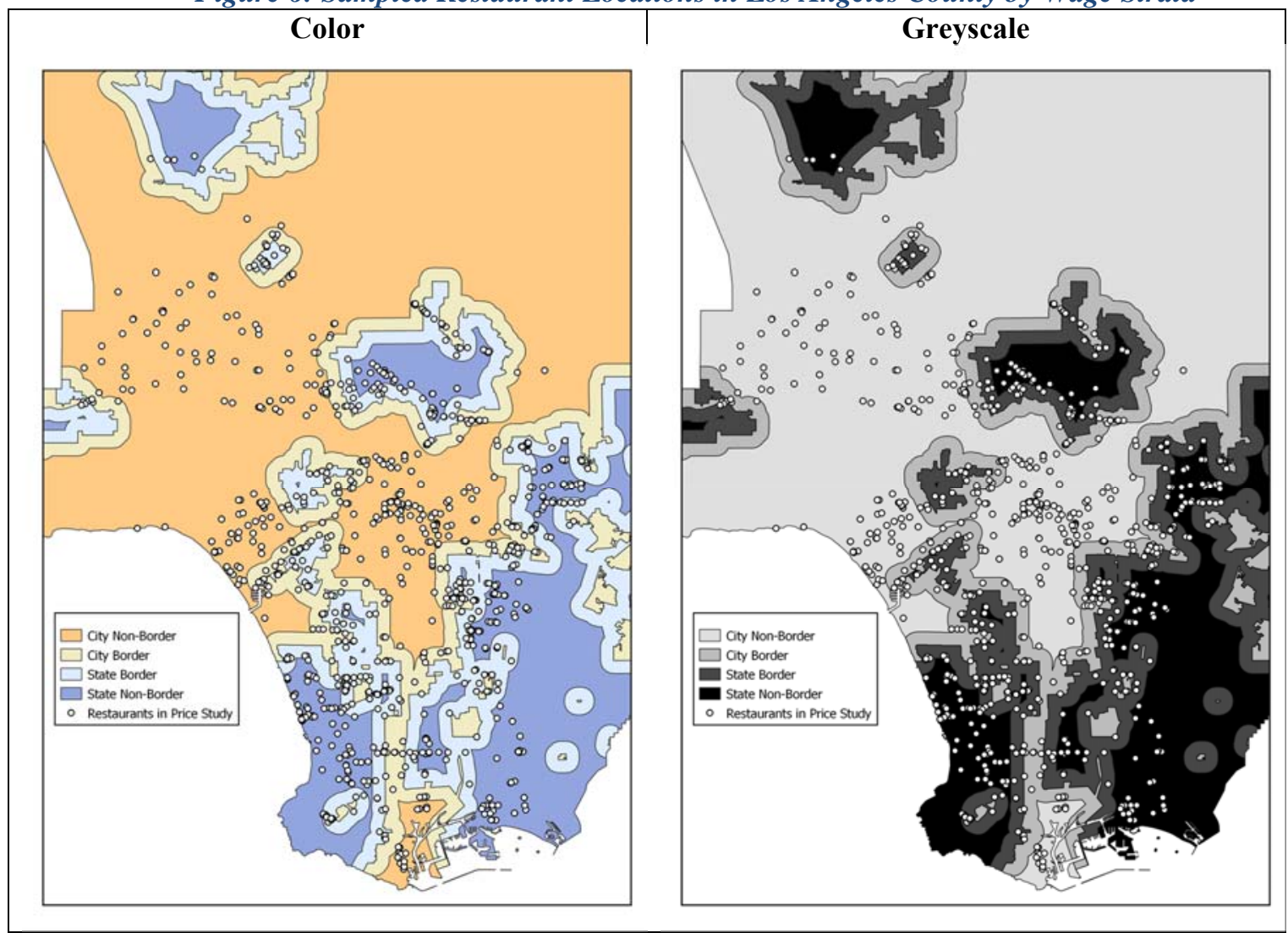

During the first round of observations, our research assistants physically visited each of the 800 restaurants in the sample and asked the employees to identify the restaurant's two most popular lowpriced entrees, the two most popular high-priced entrees, and the most popular side dish. For each item, we noted the size or quantity of the item that is sold in a standard purchase. We selected a la carte items whenever possible. We also asked employees what time of day their restaurant was usually busiest (breakfast, lunch, dinner, or a combination thereof) and recorded the health inspection grade of the restaurant (A, B, or C).

This first round of observations, involving trips to the physical locations, took place between November 2015 and December 2016. We began our second round of observations in January 2017. To spread out the sampling work over the year, starting with the second round of observations we divided our dataset of 800 restaurants into 6 bins of 133 each. We conducted observations of the restaurants in each of the 6 bins twice per year on a rolling basis, the first bin in January and July of each year, the second bin in February and August, and so on. Because the minimum wage increases occurred in January and July, the bi-annual sample design allows for an observation of the price of each item within six months of the increase and within six months after the increase. The annual schedules of increases results in two monthly observations between each change in the minimum wage.

Occasionally restaurants did not answer the phone or reported very large price changes (price increases or decreases over $50 \%$ ). We called these restaurants a second time one day later. If a restaurant continued to not answer the phone or reported price changes in excess of $50 \%$, we visited it in-person at the end of the month. Restaurants also occasionally changed their menus or closed. When an item no longer appeared on a restaurant's menu, we discontinued the old item and created a new item with a new unique identifier code. We use the menu change observations to test whether restaurants subject to the City Wage changed their menus more frequently than those subject to the 
lower State Wage. When a restaurant closed, we replaced it with the most geographically proximate restaurant, again giving the menu items new unique identifier codes. This coding allows for an analysis of restaurant closures, which we perform in Section 8.

To verify the quality of our price data, we compared the 6-month price changes from our survey with price changes from Bureau of Labor Statistics (BLS) "food away from home" price index for the Los Angeles Metropolitan Area (Figure 7). We use 3-month rolling averages to smooth the trends in the data. Though taken from different sources and imperfectly overlapping geographical regions, the price changes from our survey and the BLS data share some common patterns. For July 2017 through July 2018 , price changes recorded by the price survey were higher than those recorded by the BLS index, but the changes in the series are strongly correlated. The series depart around January 2019, when price increases recorded by the price survey decreased while CPI-recorded price increases increased. The increase the CPI index is possibly explained by the inclusion of Orange County in LA Metropolitan Area CPI but not in our price survey. Orange County is subject to the CA State minimum wage, which increased by $9.1 \%$ on January 1,2019 , so price increases associated with the CA State minimum wage increase should materialize more strongly in price increases in the BLS CPI than in our price survey. The decline in price changes from our restaurant survey around January 2019 may also be explained by the relative high frequency of LA City restaurants that appear in our price survey sample. The LA City wage increased in July in 2018 and 2019. If price increases at City restaurants occurred shortly before or after increases in the City wage, we would expect average price increases for items in our price survey to have comparatively lower price growth around January 2019. Starting in April 2019, the two price change indices reached a common level and began a slight downward trend.

Figure 7: 6-Month Price Changes (3 Month Moving Average)

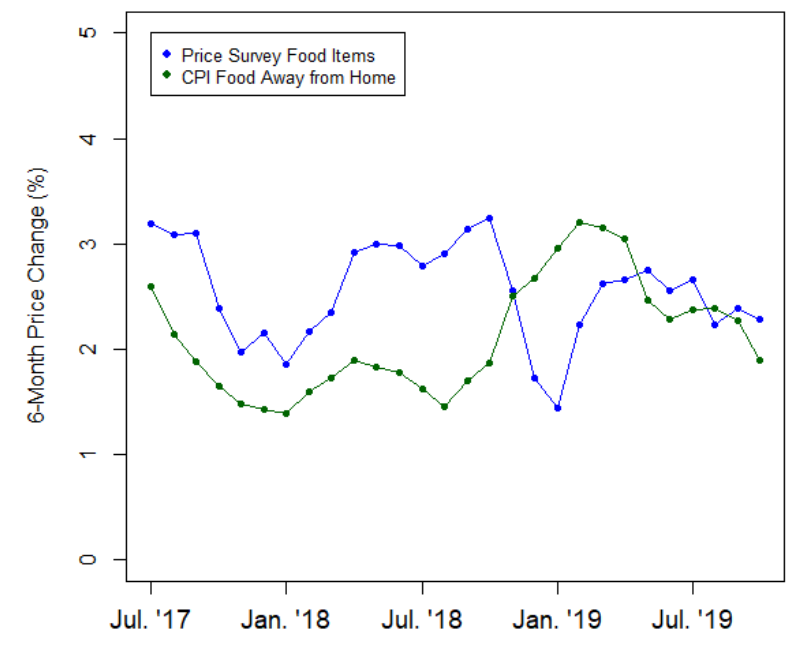

To complete our data, we collected national processed food Producer Price indexes from the BLS to account for changes in input factor prices (Figure 8). We matched the Processed Meat, Poultry, and Fish index to our entrée menu items and the Processed Cereal and Bakery Products to our side dish items. The indexes have been given the variable names PPIProtein and PPICerals in the regressions presented in the later tables. 
Figure 8: CPI and PPI Price Indices, January 2015 to December 2019

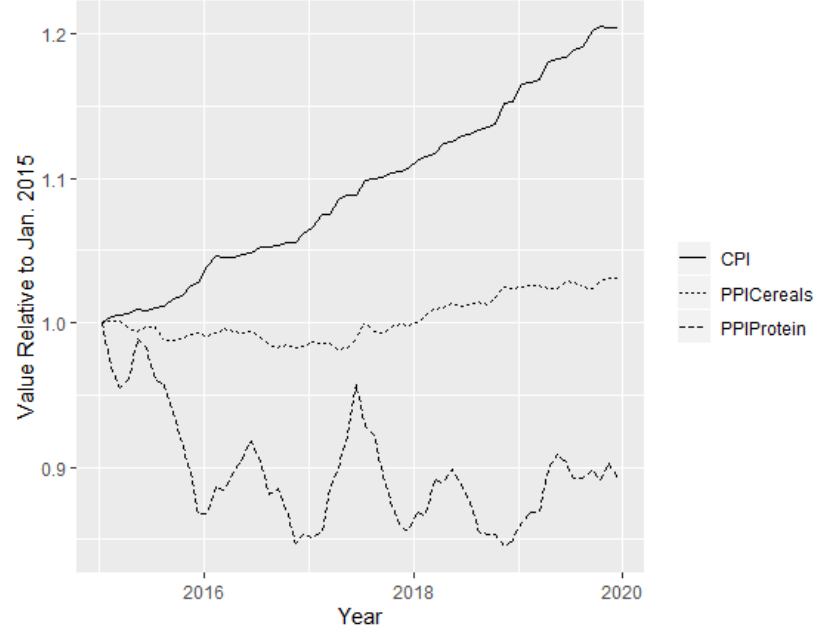

\section{Price Survey: Summary Statistics}

Although increases in the minimum wage occurred throughout the four years of the survey, we do not find restaurants responding to individual between-round increases in the minimum wage by raising prices in a way that is coordinated with the minimum wage increases. Any minimum wage increase is created by a complicated but transparent political process that makes the increase predictable in advance and which allows responses to be anticipatory as well as delayed. The legislation that governs the minimum wages in our study created a multi-year schedule of future minimum wage increases which allows restaurant responses at any point in time to depend on the whole schedule. For this reason, in the main text we present the results for restaurant price adjustments between the first and last rounds of our price surveys compared with changes in the minimum wages over the same period. The complete price survey dataset including all 7 rounds of observations is summarized in Appendix A.

Table 2 displays the number of same menu items that were observed in the same restaurants in both rounds 1 and 7, broken out by stratum and month. The cell shading denotes the statutory minimum wage when an observation was taken. Our first round of observations spanned a 14-month period during which the City and State wages were $\$ 9$ in the first two months, \$10/hour for the following 6 months, and diverged to $\$ 10 /$ hour for the State wage and $\$ 10.50 /$ hour for the City wage in the final six months. 
Table 2: Count of Matched Item Observations by Strata and Month

\begin{tabular}{|c|c|c|c|c|c|c|}
\hline & & $\begin{array}{l}\text { State Non- } \\
\text { Border }\end{array}$ & $\begin{array}{l}\text { State } \\
\text { Border }\end{array}$ & $\begin{array}{l}\text { City } \\
\text { Border }\end{array}$ & $\begin{array}{l}\text { City Non- } \\
\text { Border }\end{array}$ & Total \\
\hline \multirow{14}{*}{ 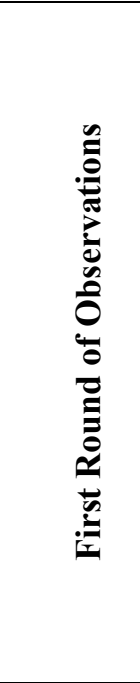 } & Nov-15 & 2 & 0 & 0 & 0 & 2 \\
\hline & Dec-15 & 390 & 467 & 241 & 302 & 1400 \\
\hline & Jan-16 & 0 & 10 & 3 & 8 & 21 \\
\hline & Feb-16 & 0 & 0 & 0 & 0 & 0 \\
\hline & Mar-16 & 3 & 28 & 37 & 108 & 176 \\
\hline & Apr-16 & 93 & 91 & 57 & 83 & 324 \\
\hline & May-16 & 0 & 0 & 0 & 0 & 0 \\
\hline & Jun-16 & 44 & 35 & 24 & 3 & 106 \\
\hline & Jul-16 & 0 & 0 & 0 & 0 & 0 \\
\hline & Aug-16 & 0 & 0 & 0 & 0 & 0 \\
\hline & Sep-16 & 0 & 4 & 13 & 22 & 39 \\
\hline & Oct-16 & 0 & 8 & 6 & 4 & 18 \\
\hline & Nov-16 & 0 & 0 & 0 & 0 & 0 \\
\hline & Dec-16 & 0 & 0 & 0 & 0 & 0 \\
\hline \multirow{7}{*}{ 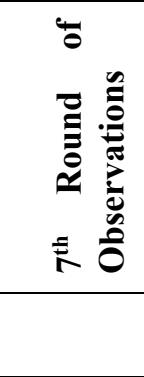 } & July-19 & 76 & 125 & 70 & 93 & 364 \\
\hline & Aug-19 & 80 & 99 & 90 & 107 & 376 \\
\hline & Sep-19 & 89 & 164 & 53 & 68 & 374 \\
\hline & Oct-19 & 80 & 110 & 70 & 75 & 335 \\
\hline & Nov-19 & 121 & 51 & 55 & 85 & 312 \\
\hline & Dec-19 & 86 & 94 & 43 & 102 & 325 \\
\hline & $\begin{array}{l}\text { Total each } \\
\text { Round }\end{array}$ & 532 & 643 & 381 & 530 & 2086 \\
\hline $\begin{array}{l}\text { Key: } \\
\text { Min } \\
\text { Wage }\end{array}$ & $\$ 9.00$ & $\$ 10.00$ & $\$ 10.50$ & $\$ 12.00$ & $\$ 14.25$ & \\
\hline
\end{tabular}

We report average price changes between rounds 1 and 7 by stratum in Table 3 . The first column reports the average price changes in the State Non-border region, which is adopted as the reference group. The next three columns report differences in the price changes between the three other regions and the reference group, thus creating three difference-in-differences comparisons. In addition to the overall comparisons, we disaggregate the sample by the median household income of the census tract where the restaurant was domiciled. We define high-income census tracts as those with median household income above the county-wide median of $\$ 59,807$ for the 5-year period leading up to 2015 based on the American Community Survey (ACS) 5-year estimates. Table 3 also displays the same data for restaurants that had above-median entrée prices in high-income census tracts during the first round of the survey. The final row of Table 3 reports the percent change in minimum wages which can be compared with the restaurant menu price changes. 
Table 3: Mean Price Change and Minimum Wage Change across Three Strata Relative to State Non-Border by Census Tract Median Household Income

\begin{tabular}{|c|c|c|c|c|c|}
\hline & & $\begin{array}{l}\text { Reference } \\
\text { Group }\end{array}$ & Percentage $P$ & Difference to & ence Group \\
\hline & & $\begin{array}{l}\text { State Non- } \\
\text { Border }\end{array}$ & State Border & City Border & $\begin{array}{l}\text { City Non- } \\
\text { Border }\end{array}$ \\
\hline \multirow{4}{*}{ 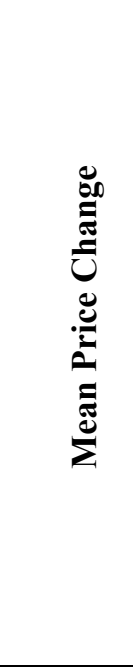 } & $\begin{array}{l}\text { All Census } \\
\text { Tracts }\end{array}$ & $\begin{array}{l}16.4 \% \\
(0.767)\end{array}$ & $1.8^{* *}$ & -0.2 & $1.9 * *$ \\
\hline & $\begin{array}{l}\text { Low-Income } \\
\text { Census Tracts }\end{array}$ & $\begin{array}{l}19.0 \% \\
(1.27)\end{array}$ & -2.4 & -0.8 & 0.7 \\
\hline & $\begin{array}{l}\text { High-Income } \\
\text { Census Tracts }\end{array}$ & $\begin{array}{l}14.0 \% \\
(0.877)\end{array}$ & $5.5 * * *$ & 0.0 & $4.4 * * *$ \\
\hline & $\begin{array}{c}\text { High-Income } \\
\text { Census Tracts } \\
\text { and } \\
\text { Restaurants } \\
\text { with High } \\
\text { Entrée Prices }\end{array}$ & $\begin{array}{l}12.9 \% \\
(1.10)\end{array}$ & $5.1 * *$ & 1.0 & $5.1 * * *$ \\
\hline 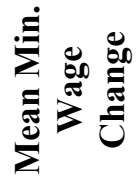 & $\begin{array}{l}\text { All Census } \\
\text { Tracts }\end{array}$ & $\begin{array}{c}29.8 \% \\
(0.0589)\end{array}$ & -0.001 & $22.4 * * *$ & $21.4 * * *$ \\
\hline
\end{tabular}

Standard errors of the reference group in parentheses. $* p<0.10 ; * * p<0.05 ; * * * p<0.01$. Percent change in the minimum wage varies slightly between the State Non-Border and the State Border, and between the City Border and the City Non-Border because the first round of item observations were taken during three different minimum wage levels (see Table 2). The mean minimum wage changes did not vary significantly between high-income and low-income census tracts within the same strata.

Minimum wages increased by $29.8 \%$ in the reference group, and restaurant prices increased by $16.4 \%$. A direct comparison of these two numbers is an inappropriate way of inferring the passthrough rate because things other than minimum wages can produce price increases. Implicit controls for these other drivers are created with the difference-in-differences displayed in the last three columns. Column 4 reports that minimum wages increased in the City Non-border region by an amount that was 21.4 percentage points higher than the reference group and the City Non-border region experienced a rise in prices that was 1.9 percentage points higher than the reference group. The ratio $1.9 / 21.4=9 \%$ is the pass-through rate suggested by these difference-in-differences data. However, the other two columns that compare with the reference group are not supportive of that pass-through conclusion. The State Border region in column 2 had minimum wages increases that were virtually the same as the reference group but had price increases 1.8 percentage points greater than the reference group, essentially the same price increase as the City Non-border which had much greater increases in minimum wages. That's a puzzle. The City Border region in column 3 had the largest minimum wage increases but experienced price increases that were essentially the same as the reference group. That's also a puzzle. 
We explore two explanations for these puzzling estimates. First the regional definitions that are embodied in Table 3 assume that all restaurants in the City within one mile of the State minimum wage border compete in the same way with restaurants in the State Border while in fact some restaurants are closer to the border than others, and some restaurants close to the border do not actually have competitors on the other side. We need to allow more complex competition across the border. Secondly, we hypothesize that we may be observing a pre-equilibrium outcome. State Border restaurants may have benefited from increased pricing power due to a higher propensity for restaurants in the City Border to close. If City Border restaurants close and new restaurants do not open quickly in their place, customer demand for restaurant meals could spill across the wage border and lead to larger price increases at nearby State Border restaurants.

Investigations of these two hypotheses are reported next, starting with data visualizations that do not depend on arbitrary assumptions about the geographical extent of competition in the restaurant business. Figure 9 presents scatter plots of food price changes as a function of distance to the border, with the minimum wage border in the middle and with restaurants subject to the State Wage on the left and subject to the City Wage on the right. In each scatterplot, we insert fit lines and two-standard error bands generated by estimating separate high-degree polynomials for the restaurants on the State Wage and the City Wage sides of the wage border. The scatters refer separately to low-income Census Tracks and high-income census tracks, based on the implicit assumption that there are two separate classes of restaurants: those serving high-income customers and those serving low-income customers.

Because conventional methods for generating fit bands such as Loess regression involve the arbitrary parameter selection, we adopt the method of Leamer (2019) which approximates an infinite polynomial regression and only involves two possible parameter sets: a near-linear or a non-linear prior distribution with the non-linear prior applicable to settings in which nonlinearities are expected. ${ }^{2}$ Our conceptual framework is explicitly non-linear.

Figure 9: Average Price Changes between Rounds 1 and 7 by Border Distance for Restaurants in Low and High-Income Census Tracts

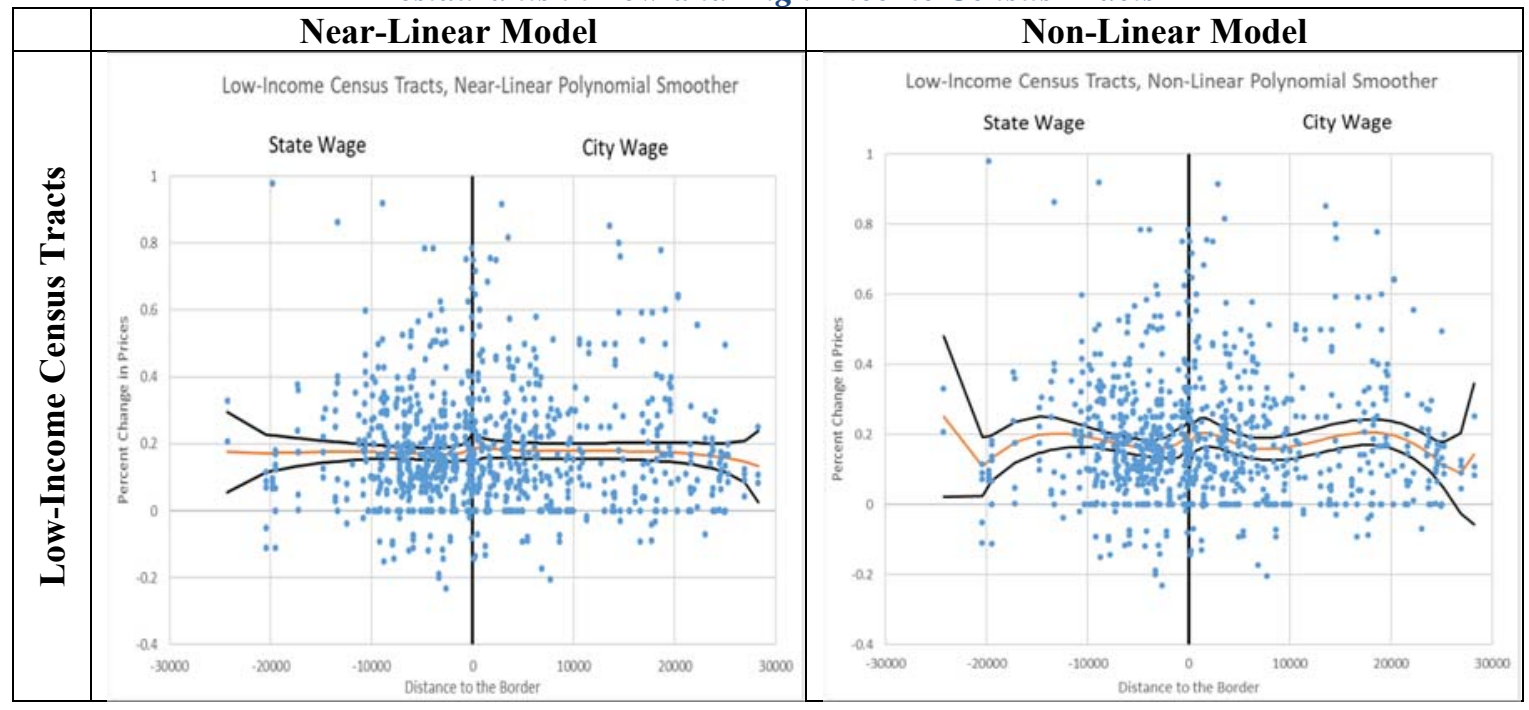

\footnotetext{
${ }^{2}$ Loess fit lines with 2-standard error bands are shown in Appendix B.
} 


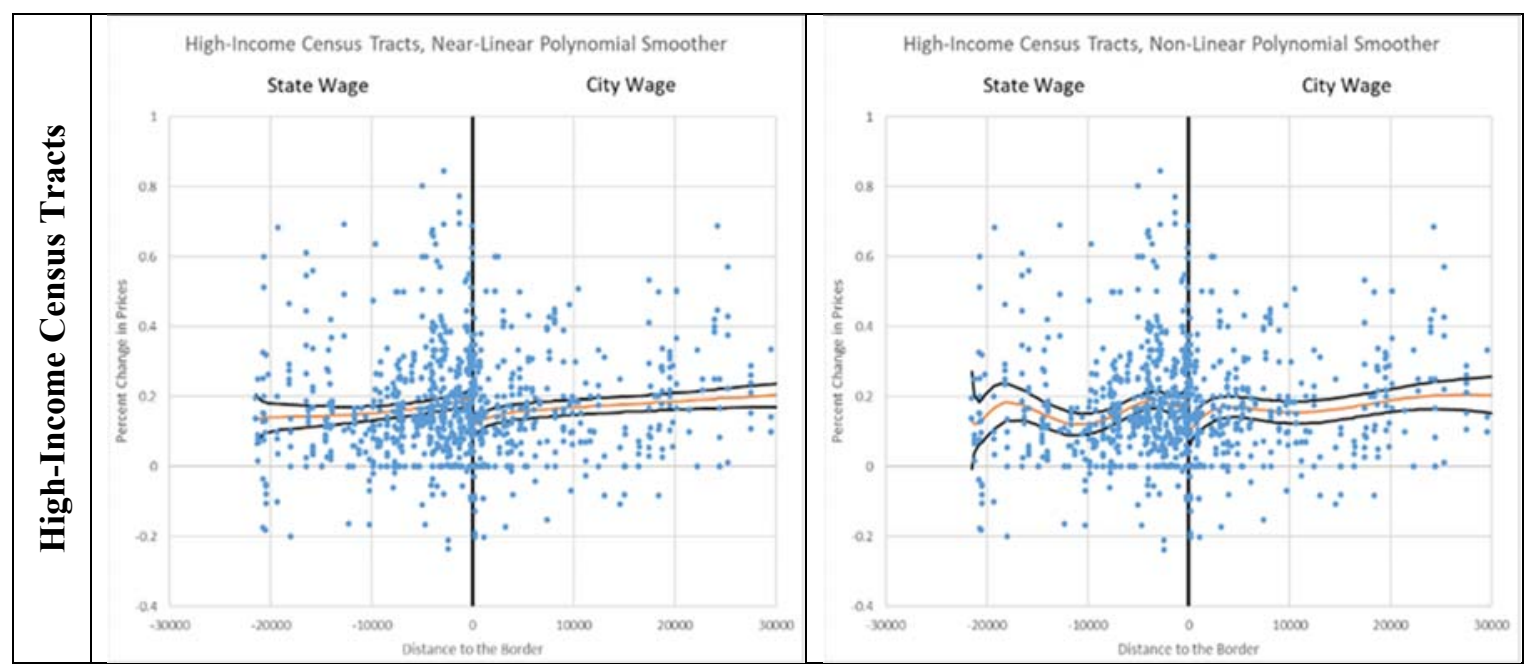

The near linear smoothing for the low-income census tracts at the top left produces a confidence set that is pretty much the same at all locations which means that there are no detectable differences in price changes for any location, close or far from the border. The high-income near-linear scatter at the bottom left is quite different with a price increase on the State side increasing with closeness to the border and decreasing on the City side and with a break at the border.

The nonlinear images are a lot more wiggly but the same conclusions arise. The Low-Income error bands at the border overlap. The high-income error bands at the border do not overlap. Therefore, the inference drawn from the non-linear model is the same as in the linear model: price increases near the wage border were smaller on the City side than on the State side. The price changes in Figure 9 are consistent with the summary statistics presented in Table 3.

These one-dimensional images are implicitly based on the assumption that what determines crossborder competition is linear distance to the border. In a two-dimensional world a restaurant can be close to the border but not close to restaurants on the other side. To analyze whether proximity to actual competitors across the border influences price changes, we defined restaurants as exposed to cross-wage-border competition based on two conditions: (1) whether they are located near to restaurants subject to the alternative minimum wage schedule, and (2) whether those nearby restaurants were in neighborhoods with similar levels of median household income. We constructed the data as follows. First, for each restaurant in the sample we identified all restaurants located within 1 mile through a search of the LA County Department of Health restaurant inspections dataset; a data set of over 20,000 establishments. Second, we defined restaurants in our sample as "exposed to crossborder competition" if one or more of the nearby restaurants was located in a region of Los Angeles County subject to the alternative minimum wage schedule. In robustness exercises, we explored other definitions of cross-border competition exposure. ${ }^{3}$ Third, we identified the census tract of each of these nearby restaurants and recorded a binary variable of $(0,1)$ if the tract was below or above the county median income. Finally, we defined each restaurant in our sample as "exposed to cross-border competition if it was located within 1 linear mile of the minimum wage border and if a majority of the nearby restaurants on the other side of the border had the same value of the binary median income variable as the restaurant in the sample.

\footnotetext{
${ }^{3}$ In a robustness exercise, we found similar results when we defined restaurants as exposed to cross-border competition if they were located within one mile of 10 or more restaurants subject to the alternative minimum wage schedule. We also found similar results when we defined restaurants as exposed to cross-border competition if a majority of the restaurants within 1 mile of them were subject to the alternative minimum wage schedule.
} 
In Table 4 we display mean price changes taken between rounds 1 and 7 of our price survey broken out by these eight groups of restaurants. The first column shows mean price changes for the reference group, State wage restaurants not exposed to City wage competitors, while columns 2-4 show price increases for the other three groups of restaurants relative to the reference group.

Table 4: Mean Price Change of Food Items by Median Household Income and by Median Household income of their Competitors across the Wage Border

\begin{tabular}{|c|c|ccc|}
\hline & Reference Group & \multicolumn{3}{|c|}{ Percentage Point Difference to Reference Group } \\
\hline & $\begin{array}{c}\text { State Restaurants Not } \\
\text { Exposed to City } \\
\text { Competition }\end{array}$ & $\begin{array}{c}\text { State } \\
\text { Restaurants } \\
\text { Exposed to } \\
\text { City } \\
\text { Competition }\end{array}$ & $\begin{array}{c}\text { City } \\
\text { Restaurants } \\
\text { Exposed to } \\
\text { State } \\
\text { Competition }\end{array}$ & $\begin{array}{c}\text { City Restaurants Not } \\
\text { Exposed to State } \\
\text { Competition }\end{array}$ \\
\hline $\begin{array}{c}\text { Items at } \\
\text { Restaurants } \\
\text { in Low- } \\
\text { Income }\end{array}$ & $17.1 \%$ & & & 1.0 \\
$\begin{array}{c}\text { Census } \\
\text { Tracts }\end{array}$ & {$[244]$} & 0.5 & $7.3 * * *$ & {$[287]$} \\
\hline $\begin{array}{c}\text { Items at } \\
\text { Restaurants } \\
\text { in High- } \\
\text { Income }\end{array}$ & $(1.24)$ & {$[95]$} & {$[33]$} & \\
$\begin{array}{c}\text { Census } \\
\text { Tracts }\end{array}$ & $14.8 \%$ & $7.8^{* *}$ & $-4.4^{* * *}$ & \\
\hline
\end{tabular}

Number of item observations in brackets. Standard errors of the reference group in parentheses. Asterisks denote statically significant differences in strata means from the reference group mean.* $p$ $<0.10$; ${ }^{* *} p<0.05 ; * * * p<0.01$. The "State Not Exposed to City Competition" replaces the State Non-Border Strata, the "State Exposed to City Competition" replaces the State Border, etc.

The results presented in Table 4 provide a robustness check on the results presented in Table 3. Both tables report exceptionally large price increases in the high-income State Border region which had the lower increase in minimum wages. Moreover, when price changes are computed between different rounds of the survey (Appendix A) the same result is obtained. This shifts attention to the preequilibrium hypothesis regarding exceptional closures of restaurants in the City Border region discussed in Section 8.

The price changes reported in Table 4 for restaurants in low-income census tracts, however, are different from our Table 3 statistics. Table 3 reports no statistically significant difference in price changes in any of the three low income regions. Table 4 reports large (7.3) and statistically significant price increases in the City Border. Caution should be exercised when interpreting this result because few observations (33) were taken of items in low-income census tracts in the City Border that were exposed to State wage competitors.

\section{Price Survey: Regression Results}

The difference-in-difference geographical structures in Tables 3 and 4 can be mimicked with a regression that explains per cent changes in prices with two variables: the first variable is the percent change in minimum wages at the restaurant and the second is the percent change in minimum wages at nearby restaurants. For restaurants located far from the wage border, these two minimum wage variables are identical and the non-border data can reveal only the sum of the effects. The estimate of the sum of the effects contrasts the non-border regional difference of price changes with the non- 
border regional difference of minimum wage changes - that's difference in differences. For restaurants that are close to the border, these two minimum wage variables are different by a fixed amount which allows us to estimate only the effect of the difference in the coefficients with the border data. Knowledge of the sum of the effects from the nonborder regions and the difference in the effects from the border regions allows separate estimates of both effects. That's what the regression will do automatically.

The second minimum wage variable, which is sometimes the same as the first, can be expressed mathematically by $\left[\left(1-\right.\right.$ Border $\left._{i}\right) * \% \Delta$ Wage $_{i}+$ Border $\left._{i} * \% \Delta W a g e_{i, \text { Alternativeschedule }}\right]$, where Border $_{i}$ is the binary wage border proximity indicator, $\% \Delta W a g e_{i}$ is the change in the minimum wage at the restaurant that serves item $i$, and $\% \Delta W a g e_{i, \text { Alternativeschedule }}$ is the change in the minimum wage of the alternative schedule.

The regression model is described by Equation 3:

$$
\text { (3) } \begin{aligned}
\% \Delta \text { Price }_{i}= & \alpha+\beta \% \Delta \text { Wage }_{i} \\
& +\theta\left[\left(1-\text { Border }_{i}\right) * \% \Delta \text { Wage }_{i}+\text { Border }_{i} * \% \Delta \text { Wage }_{i, \text { Alternativeschedule }}\right]
\end{aligned}
$$

In Equation 3, $\beta$ captures the direct effect of the change in the minimum wage at the restaurant serving food item $i$ on the price of $i$ and $\theta$ captures the spillover effect of wage changes at competing nearby restaurants on changes in the price of $i$. If item $i$ is served by a restaurant located near the wage border, some competing restaurants are located across the wage border. In Table $\mathrm{W}$, we estimate the model described by (3) separately for food items in low and high-income census tracts.

\begin{tabular}{c|c|c}
\multicolumn{3}{c}{ Table 5: Estimates of Equation 3 } \\
& $\begin{array}{c}\text { Low-Income } \\
\text { Census Tracts }\end{array}$ & $\begin{array}{c}\text { High-Income } \\
\text { Census Tracts }\end{array}$ \\
\hline$\beta$ & .0506 & 0.0456 \\
& $(.0706)$ & $(0.0588)$ \\
$\theta$ & -0.0121 & $0.245^{* * *}$ \\
& $(0.0741)$ & $(0.0644)$ \\
Intercept & $0.164^{* * *}$ & 0.0473 \\
& $(0.0402)$ & $(0.0344)$ \\
\hline Fixed effects? & No & No \\
$\mathrm{R}^{2}$ & 0.001 & 0.0318 \\
Item Observations & 1,032 & 1,039 \\
\hline
\end{tabular}

Table 5 shows that, for the model containing only items served by restaurants in low-income census tracts, there are no significant regressors. In high-income census tracts, price increases were driven by the spillover effect $(\theta)$, indicating that restaurants increased their prices when they were located near competing restaurants that were subject to larger increases in their minimum wage.

To show that our regression model is consistent with our descriptive results from Table 3 , we use the estimates of $\beta$ and $\theta$ (Table 5) to compute implied mean price changes by strata. We do so by observing that, relative to price changes in the State Non-Border stratum, price changes in the State Border stratum are captured by the spillover effect times the difference in the minimum wage change across the two wage schedules $(\theta(\% \Delta$ CityWage $-\% \Delta$ StateWage $))$, price changes in the City Border stratum are captured by the direct effect of the difference in the minimum wage change across the two wage schedules $(\beta(\% \Delta$ CityWage $-\% \Delta$ StateWage $))$, and price changes in the City Non-Border are captured by both the direct and spillover effect of differences in the minimum wage change across the two schedules $((\beta+\theta)(\% \Delta$ CityWage $-\% \Delta$ StateWage $))$. We fix $\% \Delta$ CityWage $-\% \Delta$ StateWage at 
$22 \%$, based on the values computed in Table 3 . Combining this value of $22 \%$ with the parameter estimates of $\beta$ and $\theta$ from Table 5 yields the implied price changes by strata presented in Table 6 .

Table 6: Price Changes Relative to State Non-Border (Percentage Point Differences) Implied by Equation 3

\begin{tabular}{|c|cccc|}
\hline $\begin{array}{c}\text { Census Tract } \\
\text { Income }\end{array}$ & $\begin{array}{c}\text { State Non- } \\
\text { Border }\end{array}$ & State Border & City Border & $\begin{array}{c}\text { City Non- } \\
\text { Border }\end{array}$ \\
\hline Low Income & 0 & -0.27 & 1.11 & 0.85 \\
High Income & 0 & 5.39 & 1 & 6.39 \\
\hline
\end{tabular}

The implied relative price changes in Table 6 correspond closely to the mean price changes documented in Table 3. Notably, the puzzling result that price changes in high-income census tracts were smaller in the City Border than in the State Border once again emerges from Table 6. This result may plausibly be driven by item or restaurant-level heterogeneity. An advantage of the regression framework is that it allows us to control for heterogeneity at the restaurant and item level to the extent that we observe it in our dataset. From our price survey, we have information on restaurant health inspection grades (A, B, or C), employee-reported busiest time of day (breakfast, lunch, dinner, or a combination thereof), and the type of item that was observed (low-priced entrée, high-priced entrée, or side dish). In addition, we matched the producer price indexes to each menu item using the method described in Section 5. We include these control variables as fixed effects, or in the case of the producer price indexes, as a percent change continuous variable. Equation 4 describes the resulting difference-in-difference model with our added controls, wherein $X_{i}$ is a vector of the fixed effects described above:

(4) $\% \Delta$ Price $_{i}=\beta \% \Delta$ Wage $_{i}+\theta\left[\left(1-\right.\right.$ Border $\left._{i}\right) * \% \Delta$ Wage $_{i}+$ Border $_{i} * \Delta$ Wage $\left._{i, \text { otherSchedule }}\right]$

$$
+\Gamma * \% \Delta \mathrm{PPI}_{i}+X_{i}
$$

Estimates of (4) are given in Table 7, and the implied price changes at the four strata are given in Table 8. 
Table 7: Estimates of Equation 4

\begin{tabular}{c|c|c} 
& $\begin{array}{c}\text { Low-Income } \\
\text { Census Tracts }\end{array}$ & $\begin{array}{c}\text { High-Income } \\
\text { Census Tracts }\end{array}$ \\
\hline$\beta$ & 0.0266 & 0.0287 \\
& $(0.0781)$ & $(0.0617)$ \\
$\theta$ & -0.0259 & $0.241^{* * *}$ \\
& $(0.0749)$ & $(0.0626)$ \\
$\Gamma$ & 0.165 & 0.566 \\
& $(0.471)$ & $(0.398)$ \\
\hline Fixed effects? & Yes & Yes \\
$\mathrm{R}^{2}$ & 0.0482 & 0.0811 \\
Item Observations & 1,032 & 1,039 \\
\hline
\end{tabular}

Table 8: Price Changes Relative to State Non-Border (Percentage Point Differences) Implied by Equation 4

\begin{tabular}{|c|cccc|}
\hline $\begin{array}{c}\text { Census Tract } \\
\text { Income }\end{array}$ & $\begin{array}{c}\text { State Non- } \\
\text { Border }\end{array}$ & State Border & City Border & $\begin{array}{c}\text { City Non- } \\
\text { Border }\end{array}$ \\
\hline Low Income & 0 & -0.57 & 0.59 & 0.02 \\
High Income & 0 & 5.3 & 0.63 & 5.93 \\
\hline
\end{tabular}

The results in Table 8 are not meaningfully different from those in Table 6 . Therefore, the restaurant and item-level heterogeneity measured by our control variables does not explain the differences in price changes across the four strata. In particular, Table 8 shows that price increases in the City Border were not significantly greater than those in the State Non-Border. This result deviates from the propositions of our theoretical model in Section 4 and suggests that the restaurant industry in Los Angeles did not reach a long-run equilibrium during our 5-year study.

With this caveat in mind, the results from our regression analysis allow for us to estimate the percentage of the minimum wage differential that fell on restaurant customers at restaurants located away from the minimum wage border. It is generally accepted that hourly labor costs for restaurants range from $15 \%$ to $20 \%$ of operating costs. ${ }^{4}$ Part of the labor costs come from workers with wages above the minimum wage level and so the percentage of total costs at restaurants that are impacted by minimum wage increases should fall at the lower end of that $15 \%-20 \%$ range. Between the first and last survey the difference in the change in the City and State wages was $22 \%$. Multiplying the $22 \%$ by $15 \%$ yields a $3.3 \%$ greater increase in costs at City restaurants than at State restaurants. In highincome neighborhoods where competition from the lower wage region was mitigated by distance, restaurants increased prices by 5.9 percentage points more than those in the State-Non-Border (Table 8). Thus, most if not all of the incidence of the minimum wage differential between the City and State minimum wage increases is accounted for by price increases. Virtually none of the wage differential was passed on to customers through higher prices at restaurants in low-income neighborhoods. Logically, marginal restaurants unable to raise prices due to competition should be more likely to change menu items or to close. Therefore, we examine both of these hypotheses in the following analyses.

\section{Menu Changes}

\footnotetext{
${ }^{4}$ See: https://www.restaurantowner.com/public/Restaurant-Rules-of-Thumb-Industry-Averages-Standards.cfm
} 
In addition to increasing prices, restaurants can respond to increases in the cost of labor by changing their menus. Changing menu items allows restaurants to substitute less expensive ingredients in their products. In Table 9 the percentage of restaurants that changed their menus over the course of the study is reported. A menu change is defined as the discontinuation of one of the items being tracked by the survey. The menu change frequency in the State Non-Border region is the reference group in the table. Restaurants that closed prior to the last survey were excluded. There were 631 restaurants in our study that did not close, 484 of which discontinued at least one menu item. Menu changes in City Non-Border low-income census tracts were the highest in the sample. In the Card and Kruger (1994) study, limited-service restaurants increased prices similar to the increases we found for restaurants in City Non-Border high-income census tracts. Their study focused on chain restaurants in Pennsylvania and New Jersey across each state. For chain restaurants, consistency of menu items across the two states would have been important and therefore the opportunity to make menu items changes in response to differential minimum wages would have been limited. Most of the restaurants in our study were not chains, leaving greater opportunity for substituting menu changes for price increases.

Table 9: Percentage of Restaurants with at least one Menu Change

\begin{tabular}{|c|c|c|c|c|}
\hline & \multirow{2}{*}{$\begin{array}{c}\text { Reference } \\
\text { Group }\end{array}$} & \multicolumn{3}{|c|}{$\begin{array}{c}\text { Percentage of Restaurants with Menu Changes } \\
\text { Relative to Reference Group }\end{array}$} \\
\hline & & State Border & City Border & $\begin{array}{l}\text { City Non- } \\
\text { Border }\end{array}$ \\
\hline $\begin{array}{c}\text { Low Income } \\
\text { Census } \\
\text { Tracts }\end{array}$ & $\begin{array}{c}74.3 \% \\
{[74]}\end{array}$ & $\begin{array}{c}4.3 \% \\
{[83]}\end{array}$ & $\begin{array}{l}4.5 \% \\
{[52]}\end{array}$ & $\begin{array}{c}13.3 \% \\
{[97]}\end{array}$ \\
\hline $\begin{array}{c}\text { High Income } \\
\text { Census } \\
\text { Tracts } \\
\end{array}$ & $\begin{array}{c}71.6 \% \\
{[81]}\end{array}$ & $\begin{array}{l}-0.6 \% \\
{[107]}\end{array}$ & $\begin{array}{l}5.0 \% \\
{[64]}\end{array}$ & $\begin{array}{c}3.7 \% \\
{[73]}\end{array}$ \\
\hline
\end{tabular}

Number of restaurant observations in brackets.

The above table provides evidence that restaurants changed their menus more frequently when subjected to the larger increase in the minimum wage. This result was particularly apparent among restaurants in high-income census tracts, where City Border and City Non-Border restaurants were respectively 4.5 and 13.3 percentage points more likely to change their menus than the reference group. If changes in menu items in response to the higher minimum wage are attempts by the restaurant to lower costs, then at least some of the incidence of the wage was borne by customers who purchased the inferior food items. Although we cannot determine if the menu changes served that purpose, the fact that they occurred more often at restaurants in low-income neighborhoods - where, as we found earlier, price increases were smaller- suggests that they may have been implemented to reduce costs.

\section{Restaurant Closures}

The ability for restaurants to offset the cost of minimum wage increases through price increases has been shown to depend on the affluence of the neighborhood in which they are located. The lack of differential price increases in low-income City Wage restaurants was shown to lead to more menu item changes. For marginal restaurants in low-income City Wage Border census tracts where menu changes were not as prevalent as for City Wage Non-Border restaurants, a higher rate of failure is also expected.

Because we physically visited each restaurant that did not answer the phone when we called to gather price information, our price survey generated first-hand records of restaurant closures within our original sample. Figure 10 is a heat map of restaurant closures comparing those from our sample and those inferred from Los Angeles County health department data. The dots are the closures in our sample. The shaded areas are the health department closures. Of the 800 initial restaurants in our sample 166 closed by the end of the four year survey. 
Figure 10: Heat Map of Restaurant Closures in L.A. County

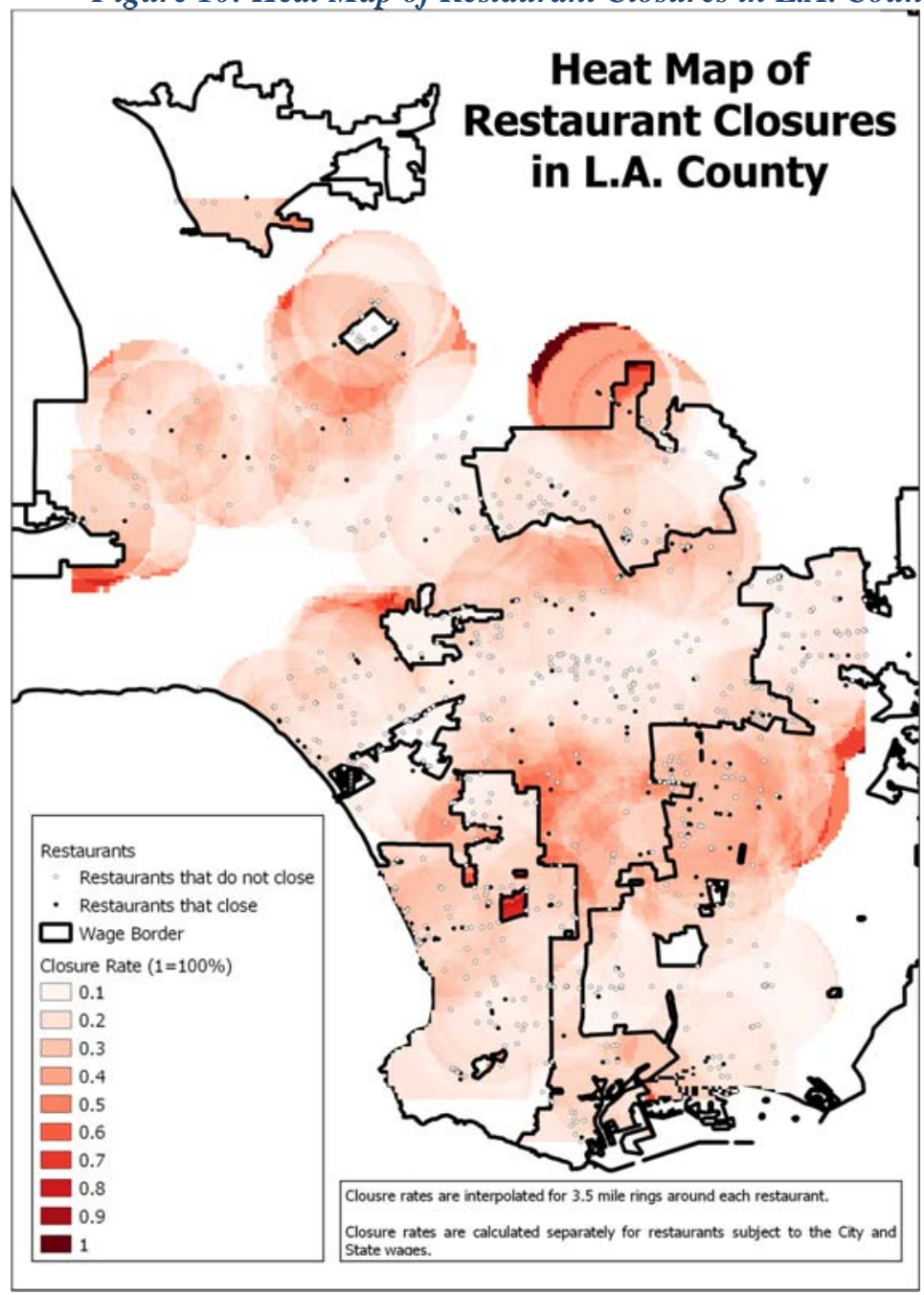

The closure rate was notably higher in the southern portion of the City Wage Region. This is a part of the county with a larger proportion of lower income census tracts. The interior parts of the City Wage region and, Beverly Hills, West Hollywood, and Culver City in the State Wage region, more affluent parts of the county, had relatively low closure rates. In Table 10, we aggregate closures and compute closure rates at the strata level and, with raw closure rates reported for the reference group of restaurants (the State Non-Border) and closure rates relative to the reference group for the other three strata. 
Table 10: Restaurant Closure Rate by Strata and Market Segment

\begin{tabular}{|c|c|ccc|}
\hline & Reference Group & \multicolumn{3}{|c|}{ Closure Rate Relative to Reference Group } \\
\hline & $\begin{array}{c}\text { State Non- } \\
\text { Border }\end{array}$ & State Border & City Border & City Non-Border \\
\hline $\begin{array}{c}\text { Restaurants in } \\
\text { Low-Income } \\
\text { Census Tracts }\end{array}$ & $\begin{array}{c}18.4 \% \\
{[97]}\end{array}$ & $-2.3 \%$ & $6.9 \%$ & $-5 \%$ \\
\hline $\begin{array}{c}\text { Restaurants in } \\
\text { High-Income }\end{array}$ & $21.6 \%$ & $1.2 \%$ & {$[84]$} & {$[125]$} \\
Census Tracts & {$[98]$} & {$[124]$} & $7.0 \%$ & $-0.8 \%$ \\
\end{tabular}

Number of initial restaurant observations in brackets

Closure rates for restaurants in both high and low-income census tracts are shown to be higher in the City Border in Table 10. For robustness, we investigated the closure rate of restaurants using the alternative cross-border competitor construction described in Section 3. We report these results in Table 11. The first column of the table shows the closure rate for the reference group, State Wage restaurants not exposed to City Wage competitors. Columns 2-4 show closure rates relative to the reference group.

Table 11: Closure Rate of State and City Restaurants Relative to Reference Group by Market Segment of Competition

\begin{tabular}{|c|c|c|c|c|}
\hline & Reference Set & \multicolumn{3}{|c|}{ Closure Rate Relative to Reference Set } \\
\hline & $\begin{array}{c}\text { State } \\
\text { Restaurants Not } \\
\text { Exposed to City } \\
\text { Competitors }\end{array}$ & $\begin{array}{c}\text { State } \\
\text { Restaurants } \\
\text { Exposed to City } \\
\text { Competitors } \\
\text { near Households } \\
\text { with Similar } \\
\text { Income } \\
\end{array}$ & $\begin{array}{l}\text { City Restaurants } \\
\text { Exposed to State } \\
\text { Competitors } \\
\text { near Households } \\
\text { with Similar } \\
\text { Income }\end{array}$ & $\begin{array}{c}\text { City Restaurants } \\
\text { Not Exposed to } \\
\text { State } \\
\text { Competitors }\end{array}$ \\
\hline $\begin{array}{l}\text { Restaurants in } \\
\text { Low-Income } \\
\text { Census Tracts }\end{array}$ & $\begin{array}{c}25.6 \% \\
{[121]}\end{array}$ & $\begin{array}{c}-10 \% \\
{[45]}\end{array}$ & $\begin{array}{l}8.9 \% \\
{[29]}\end{array}$ & $\begin{array}{c}-1.6 \% \\
{[150]}\end{array}$ \\
\hline $\begin{array}{l}\text { Restaurants in } \\
\text { High-Income } \\
\text { Census Tracts }\end{array}$ & $\begin{array}{c}23.6 \% \\
{[123]}\end{array}$ & $\begin{array}{c}-9.4 \% \\
{[57]}\end{array}$ & $\begin{array}{c}2.5 \% \\
{[46]}\end{array}$ & $\begin{array}{c}-9.6 \% \\
{[93]}\end{array}$ \\
\hline
\end{tabular}

Number of restaurant observations in brackets.

State Wage Non-Border restaurants had a closure rate of $25.6 \%$ in low-income neighborhoods and $23.6 \%$ in high-income neighborhoods respectively. State Wage Border restaurants had lower closure rates, and City Wage Border restaurants had higher closure rates. The highest closure rates were for City Wage restaurants in low-income tracts that bordered on State Wage, low-income census tracts. In the City Wage region, the lowest closure rate was in the Non-Border high-income census tracts. is the same group of restaurants that also increased prices by the largest amount. 


\section{Conclusion}

Our study of LA County restaurant prices and closures spanning the period November 2015 to December 2019 found that the incidence of the higher increase in the minimum wage in the City Wage region depended on the market segment that restaurants served and the restaurants' proximity to competitors subject to the lower minimum State Wage. These results tie together disparate conclusions about the incidence of the minimum wage in many of the other studies on this topic. Specifically, we found that restaurants in high-income neighborhoods and located far from lowerwage competition passed most of the City Wage differential through to their customers by raising prices. Restaurants in low-income neighborhoods including those located near lower-wage competition were found to not have larger price increases than those in the State Wage region. Instead, restaurants in low-income neighborhoods changed their menus more often and restaurants exposed to lower-wage competition were more likely to close. We infer that the spatial discontinuity in minimum wages caused demand for restaurant meals to spill across the wage border and to nearby restaurants subject to the State Wage. In support of this inference, we found that State Wage restaurants in high-income census tracts and located near City Wage competition increased prices and were less likely to close than their nearby City Wage competitors.

These results suggest that policy makers face an important dilemma when designing minimum wage policies to redistribute income while minimizing job loss. On one hand, our finding that restaurants in high-income neighborhoods passed on the full incidence of the minimum wage differential to their customers suggests that minimum wages should be set relative to local income levels. The price passthrough channel for income redistribution is optimized when minimum wages are set uniquely for fine-grained spatial units, such as neighborhoods, within which the elasticity of demand for restaurant meals is homogenous. On the other hand, our findings indicate that customers' demand for restaurant meals can spill across jurisdictional borders with different minimum wages. Therefore, different minimum wages across fine-grained spatial units have the potential to move customer demand, jobs, and tax revenue out of jurisdictions that enact higher minimum wages. A universal minimum wage increase is not sensitive to this heterogeneity in the elasticity of demand, while minimum wage increases enacted at the neighborhood scale may cause restaurants to relocate out of higher-wage areas. The optimal spatial scale for setting minimum wages must balance these two offsetting forces.

In addition to these policy considerations, our study raises the possibility that some of the incidence of minimum wage increases falls on landlords. Our theoretical model predicts that land rents in regions subject to larger minimum wages will decrease, particularly at locations close to areas with lower minimum wages (Figure 5). This proposition strengthens because restaurant properties have specific use characteristics which are costly to change. That is, the costs sunk into the building fit out of kitchens and service space and the cost to convert that space to alternative uses implies that landlords will accept lower rents for their properties. Our dataset does not contain records on restaurant real estate rents that extend back before the start of the minimum wage differential in Los Angeles, and therefore, we are unable to empirically test this proposition. Nonetheless, it promises to be an important area for further research.

Finally, we conclude with a note of caution. Our finding that City Wage restaurants located near the wage border as well City Wage restaurants located in low-income census tracts that remained in business were more likely to change their menus. These menu changes could either reflect a decrease in the quality of food items, or a change in restaurants' business models. Restaurants which adapt their business models may shift to less labor-intensive production, especially in the long-run. While our analysis of QCEW data in section 2 suggested that a reduction in labor intensity did not take place in Los Angeles County between 2014 and 2019, our study does not extend beyond the expansion phase of a protracted business cycle. 


\section{References}

Aaronson, Daniel. 2001. "Price Pass-Through and The Minimum Wage." Review of Economics and Statistics. Vol:83.1. Pp:158-169.

Aaronson, Daniel, Eric French, and James MacDonald. 2008. "The Minimum Wage, Restaurant Prices, and Labor Market Structure.” Journal of Human Resources. Vol:XLIII: Pp:688-720.

Andreyeva, Tatiana, Michael W. Long, and Kelly D. Brownell. 2010. "The Impact of Food Prices on Consumption: A Systematic Review of Research on the Price Elasticity of Demand for Food." American Journal of Public Health Vol:100.2. Pp:216-222.

Bernd, Frick, Gergaud, Olivier, and Saulais, Laure. 2015. Demand for Table Service Restaurants in Europe, working paper.

Byrne, Patrick J., Capps, Oral Jr., and Saha, Atanu. 1996. Analysis of Food-Away-From-Home Expenditure Patterns For US Households 1982-89. American Journal of Agricultural Economics. Vol:78:3. Pp:614-627.

Card, David and Krueger, Alan B. 1994. Minimum Wages and Employment: A Case Study of The Fast Food Industry in New Jersey and Pennsylvania, American Economic Review. Vol.84:4. Pp:772793.

Cengiz, Doruk, Arindrajit Dube, Attila Lindner, and Ben Zipperer. 2019. The Effect of Minimum Wages on Low-Wage Jobs: Evidence from the United States Using a Bunching Estimator. Forthcoming Quarterly Journal of Economics. Vol:134:3. Pp:1405-1454.

Dube, Arindrajit, Lester, T. William, and Reich, Michael. 2010. "Minimum Wage Effects Across State Borders: Estimates Using Contiguous Counties." Review of Economics and Statistics. Vol:92:4. Pp:945-964.

Graddy, Kathryn. 1997. Do Fast-Food Chains Price Discriminate on the Race and Income Characteristics of an Area? Journal of Business and Economic Statistics, Vol:15:4. Pp:391-401.

Grimes, D. R., Prime, P. B., and Walker, M. B. 2019. Geographical Variation in Wages of Workers in Low-Wage Service Occupations: A U.S. Metropolitan Area Analysis. Economic Development Quarterly. Vol:33:2. Pp:121-133.

Harasztosi, Peter and Attila Lindner. Who Pays for the Minimum Wage? American Economic Review. Forthcoming.

Khan, Tamkeen M. Powell, Lisa and Wada, Roy. 2012. Fast Food Consumption and Food Prices: Evidence from Panel Data on 5th and 8th Grade Children. Journal of Obesity. Special Issue:Behavioral Determinants of Obesity: Research Findings and Policy Implications. Pp:1-8.

Kim, Hong Soon and SooCheong Jang. 2019. "Minimum wage increase and firm productivity: Evidence from the restaurant industry" Tourism Management, Vol:71. Pp:378-388.

Leamer, Edward E. 1999. "Effort, Wages and the International Division of Labor," Journal of Political Economy, Vol. 107, Number 6, Part1, Dec 1999, 1127-1163, reprinted in Singer, Hans et.al. New World Order Series, Vol:20. 2001. 
Leamer, Edward E. (2019). An Infinite Polynomial Is an Alternative to Semiparametric Regression. Working paper.

Lee, Jonq-Ying and Brown, Mark G. 1986. Food Expenditures At Home and Away From Home In The United States A Switching Regression Analysis, Review of Economics and Statistics. Vol:68:1. Pp:142-147.

Lemos, Sara. 2008 A Survey of The Effects of The Minimum Wages on Prices. Journal of Economic Surveys. Vol:22.1. Pp:187-212.

McCracken, Vicki A. and Brandt, John A. 1987. Household Consumption of Food Away From Home: Total Expenditure By Type of Food Facility. American Journal of Agricultural Economics. Vol:69:2. Pp:274-284.

Neumark, David and Wascher, William L. 2008. Minimum Wages. MIT Press.

Richards, Timothy J. and Mancino, Lisa. 2013. Demand for food-away-from-home: a multiplediscrete-continuous extreme value model. European Review of Agricultural Economics. Vol:4.1. Pp:111-133.

S\&P CoreLogic Case-Shiller Home Price Indices: Methodology.

http://us.spindices.com/documents/methodologies/methodology-sp-cs-home-price-indices.pdf 


\section{Appendices}

Appendix A: Analysis of individual increases in the minimum wages.

Appendix A provides summary statistics, including observation counts, minimum wage changes, and price changes, for the full price survey dataset continuing rounds 1 through 7 of the sample. Our analysis of this complete data suggests that restaurants did not increase prices in response to the between-round individual increases in the minimum wage.

Table A1 shows the number of matched item observations between each pair of rounds, broken out by strata. Shading in the table cells corresponds to a change in the minimum wage between when those items were observed. A small number of our observations during round 1 were conducted after the City and State minimum wages rose above $\$ 9 /$ hour. Therefore, the wage changes between rounds 1 and 2 are expressed as a range.

Table A1: Number of Repeat Observations of Items between Rounds

\begin{tabular}{|c|c|c|c|c|c|c|}
\hline & $\begin{array}{c}\text { Month of } \\
\text { Repeat } \\
\text { Observation }\end{array}$ & $\begin{array}{l}\text { State Non- } \\
\text { Border }\end{array}$ & $\begin{array}{c}\text { State } \\
\text { Border }\end{array}$ & $\begin{array}{c}\text { City } \\
\text { Border }\end{array}$ & $\begin{array}{l}\text { City Non- } \\
\text { Border }\end{array}$ & Total \\
\hline \multirow{6}{*}{ 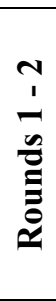 } & Jan-17 & 49 & 60 & 67 & 55 & 231 \\
\hline & Feb-17 & 47 & 54 & 38 & 63 & 202 \\
\hline & Mar-17 & 50 & 54 & 39 & 54 & 197 \\
\hline & April-17 & 66 & 70 & 50 & 42 & 228 \\
\hline & May-17 & 58 & 63 & 58 & 47 & 226 \\
\hline & June-17 & 32 & 47 & 25 & 61 & 165 \\
\hline \multirow{6}{*}{ 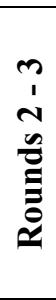 } & July-17 & 41 & 37 & 59 & 53 & 190 \\
\hline & Aug-17 & 51 & 55 & 57 & 97 & 260 \\
\hline & Sep-17 & 74 & 77 & 51 & 90 & 292 \\
\hline & Oct-17 & 42 & 93 & 54 & 58 & 247 \\
\hline & Nov-17 & 78 & 69 & 57 & 51 & 255 \\
\hline & Dec-17 & 62 & 53 & 28 & 64 & 207 \\
\hline \multirow{6}{*}{ 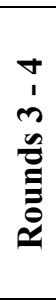 } & Jan-18 & 47 & 55 & 77 & 66 & 245 \\
\hline & Feb-18 & 39 & 68 & 51 & 96 & 254 \\
\hline & Mar-18 & 46 & 61 & 45 & 68 & 220 \\
\hline & April-18 & 55 & 99 & 53 & 61 & 268 \\
\hline & May-18 & 73 & 74 & 74 & 52 & 273 \\
\hline & June-18 & 67 & 55 & 38 & 69 & 229 \\
\hline \multirow{6}{*}{ 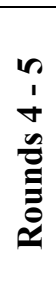 } & July-18 & 44 & 61 & 65 & 64 & 234 \\
\hline & Aug-18 & 63 & 73 & 45 & 78 & 259 \\
\hline & Sep-18 & 50 & 53 & 36 & 66 & 205 \\
\hline & Oct-18 & 67 & 80 & 66 & 53 & 266 \\
\hline & Nov-18 & 60 & 66 & 44 & 55 & 225 \\
\hline & Dec-18 & 64 & 56 & 32 & 63 & 215 \\
\hline \multirow{5}{*}{ 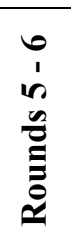 } & Jan-19 & 41 & 54 & 51 & 60 & 206 \\
\hline & Feb-19 & 54 & 62 & 34 & 58 & 208 \\
\hline & Mar-19 & 49 & 50 & 30 & 60 & 189 \\
\hline & April-19 & 46 & 66 & 46 & 45 & 203 \\
\hline & Мay-19 & 50 & 63 & 32 & 45 & 190 \\
\hline
\end{tabular}




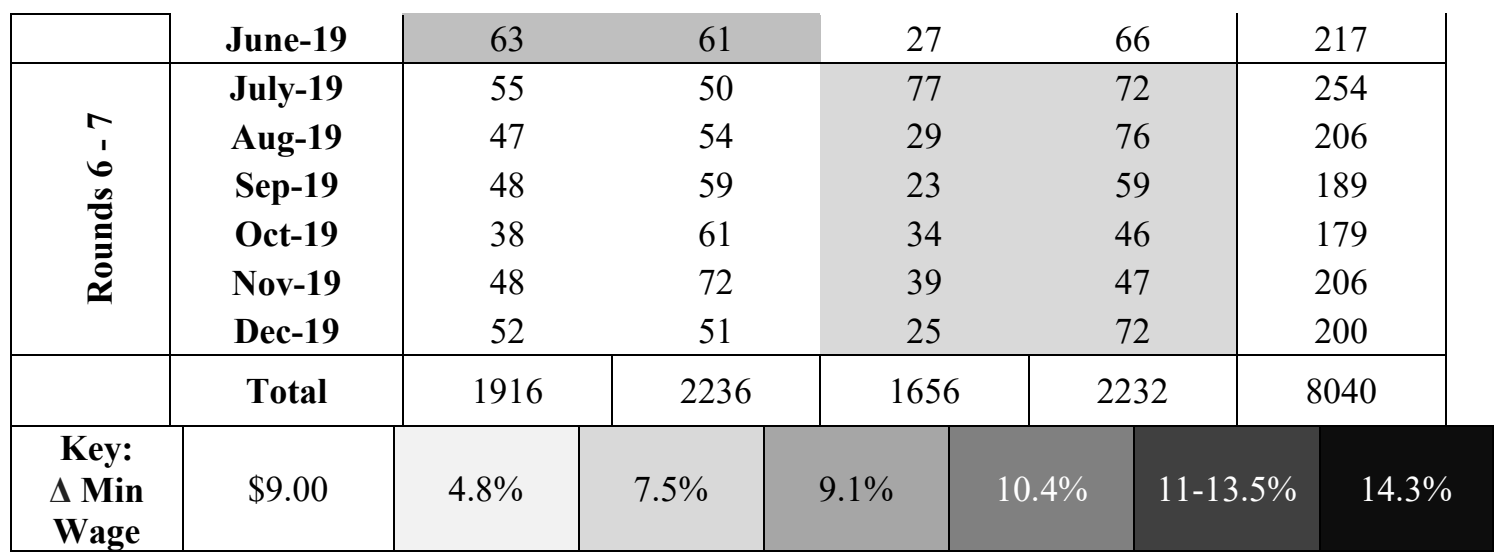

Note: Wage increases between the first and second round are expressed as a range because the wage increase for each restaurant depended on the month and year it was observed in the first round (see Table 1 in main text)

Table A2 summarizes the average price changes for all matched items in our dataset. Price changes are annualized because the observations taken in rounds 1 and 2 were not always exactly 6 months apart. From the table, it is difficult to discern a relationship between increases in the statutory minimum wage and changes in item prices. Between rounds 2 and 3, for example, the City Wage rose by $14.3 \%$ while the State Wage did not increase. However, restaurants in the State Non-Border increased prices by an annualized 5.8\% while restaurants in the City Non-Border increased prices by an annualized 4.3\%. While the increases in the City Wage between rounds 4 and 5 and between 6 and 7 , and the increase in the State Wage between rounds 5 and 6 appear to be associated with increases in prices, we cannot conclude that this is a robust relationship.

Table A2: Annualized Price Changes

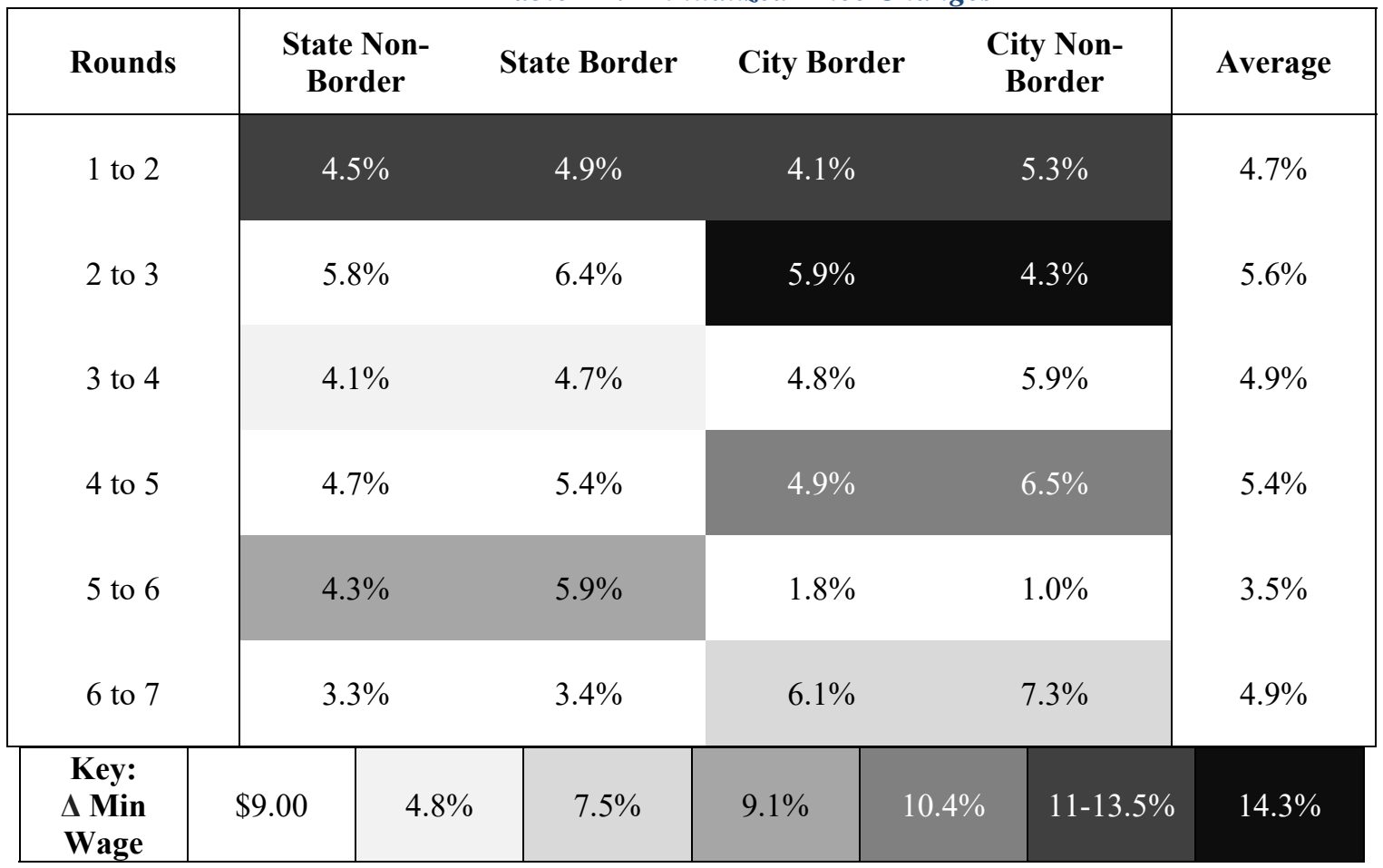

Table A3 again summarizes mean price changes by strata broken down by restaurants in high-income census tracts (those with above-average median household income) and low-income census tracts. Price changes between rounds 2 and 3 are shown to be greater at restaurants which were not subjected 
to a minimum wage increase during that time period. Beyond that, it is difficult to a relationship between increases in the minimum wage and restaurant prices.

Table A3: Low and High-Income Neighborhoods Annualized Price Changes

\begin{tabular}{|c|c|c|c|c|c|c|c|c|}
\hline \multirow[b]{2}{*}{ Rounds } & \multicolumn{4}{|c|}{ Low-Income Census Tracts } & \multicolumn{4}{|c|}{ High-Income Census Tracts } \\
\hline & $\begin{array}{c}\text { State } \\
\text { Non- } \\
\text { Border }\end{array}$ & $\begin{array}{l}\text { State } \\
\text { Border }\end{array}$ & $\begin{array}{c}\text { City } \\
\text { Border }\end{array}$ & $\begin{array}{c}\text { City } \\
\text { Non- } \\
\text { Border }\end{array}$ & $\begin{array}{l}\text { State } \\
\text { Non- } \\
\text { Border }\end{array}$ & $\begin{array}{c}\text { State } \\
\text { Border }\end{array}$ & $\begin{array}{c}\text { City } \\
\text { Border }\end{array}$ & $\begin{array}{c}\text { City } \\
\text { Non- } \\
\text { Border }\end{array}$ \\
\hline 1 to 2 & $5.1 \%$ & $4.2 \%$ & $4.2 \%$ & $5.9 \%$ & $3.9 \%$ & $5.4 \%$ & $3.9 \%$ & $4.3 \%$ \\
\hline 2 to 3 & $6.9 \%$ & $6.7 \%$ & $6.0 \%$ & $3.7 \%$ & $5.0 \%$ & $6.3 \%$ & $5.9 \%$ & $5.3 \%$ \\
\hline 3 to 4 & $4.2 \%$ & $4.1 \%$ & $5.5 \%$ & $4.8 \%$ & $3.9 \%$ & $5.2 \%$ & $4.0 \%$ & $7.2 \%$ \\
\hline 4 to 5 & $5.2 \%$ & $6.2 \%$ & $6.3 \%$ & $8.4 \%$ & $4.3 \%$ & $4.6 \%$ & $3.7 \%$ & $4.3 \%$ \\
\hline 5 to 6 & $6.1 \%$ & $5.0 \%$ & $1.8 \%$ & $0.5 \%$ & $2.7 \%$ & $6.7 \%$ & $1.8 \%$ & $1.6 \%$ \\
\hline 6 to 7 & $3.5 \%$ & $3.1 \%$ & $8.3 \%$ & $6.5 \%$ & $3.3 \%$ & $3.4 \%$ & $3.5 \%$ & $8.4 \%$ \\
\hline $\begin{array}{c}\text { Key: } \\
\Delta \text { Min } \\
\text { Wage }\end{array}$ & $0 \%$ & $4.8 \%$ & & & $1 \%$ & $10.4 \%$ & $11-13.5 \%$ & $14.3 \%$ \\
\hline
\end{tabular}

The charts below, show the difference in prices by restaurants and fitted Loess regressions with $100 \%$ search ranges.

Figure A4: Differences in Food Item Prices by Distance to Wage Border with 100\% Search

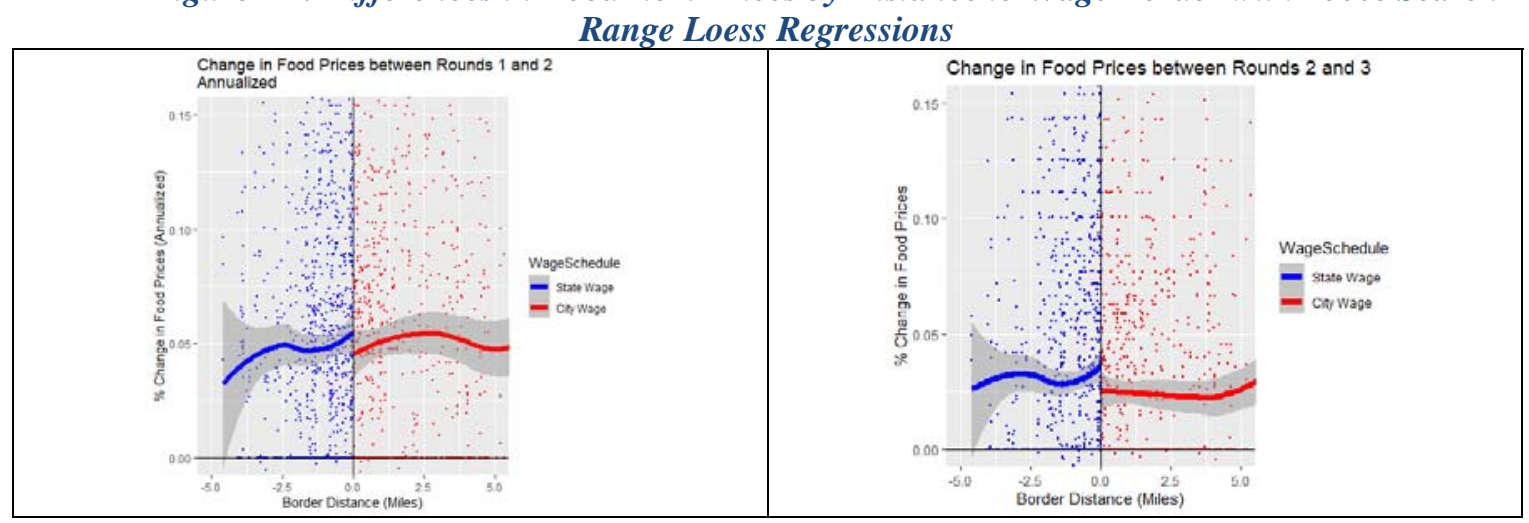




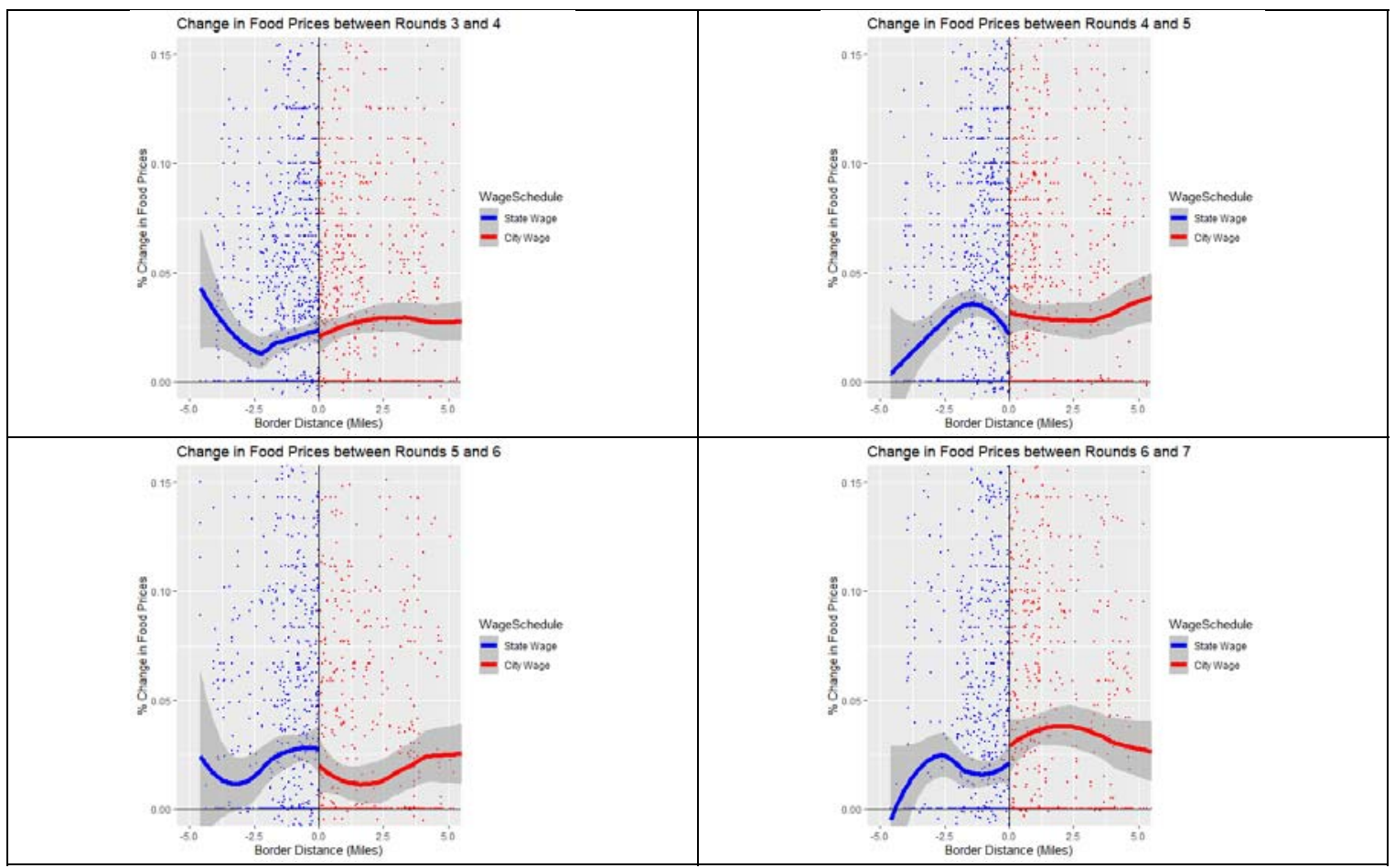

Table A4 shows closure rates in the sample by round and strata.

Figure A5: Closure Rate of Restaurants by Round and Strata

\begin{tabular}{|c|c|c|c|c|c|c|c|c|c|}
\hline & \multicolumn{7}{|c|}{ Round of Observation } & \multirow{2}{*}{$\begin{array}{c}\text { Cumulative } \\
\text { Totals }\end{array}$} \\
\hline & & 1 & 2 & 3 & 4 & 5 & 6 & 7 & \\
\hline \multirow{6}{*}{$\begin{array}{c}\text { State } \\
\text { Wage } \\
\text { Non- } \\
\text { Border } \\
\text { State } \\
\text { Wage } \\
\text { Border }\end{array}$} & Open & 195 & 188 & 182 & 177 & 169 & 162 & 156 & \\
\hline & Closed & 0 & 7 & 6 & 5 & 8 & 7 & 6 & 39 \\
\hline & \% Closed & 0 & $3.6 \%$ & $3.2 \%$ & $2.8 \%$ & $4.7 \%$ & $4.1 \%$ & $3.7 \%$ & $20 \%$ \\
\hline & Open & 238 & 230 & 218 & 214 & 209 & 203 & 192 & \\
\hline & Closed & 0 & 8 & 12 & 4 & 5 & 6 & 11 & 46 \\
\hline & $\%$ Closed & 0 & $3.4 \%$ & $5.2 \%$ & $1.8 \%$ & $2.3 \%$ & $2.9 \%$ & $5.4 \%$ & $19 \%$ \\
\hline \multirow{6}{*}{$\begin{array}{c}\text { City } \\
\text { Wage } \\
\text { Border } \\
\text { City } \\
\text { Wage } \\
\text { Non- } \\
\text { Border }\end{array}$} & Open & 159 & 151 & 144 & 142 & 132 & 124 & 116 & \\
\hline & Closed & 0 & 8 & 7 & 2 & 10 & 8 & 8 & 43 \\
\hline & $\%$ Closed & 0 & $5 \%$ & $4.6 \%$ & $1.4 \%$ & $7 \%$ & $6.1 \%$ & $6.5 \%$ & $27 \%$ \\
\hline & Open & 207 & 200 & 196 & 191 & 183 & 175 & 171 & \\
\hline & Closed & 0 & 7 & 4 & 5 & 8 & 8 & 4 & 36 \\
\hline & $\%$ Closed & 0 & $3.4 \%$ & $2 \%$ & $2.6 \%$ & $4.2 \%$ & $4.4 \%$ & $2.3 \%$ & $17 \%$ \\
\hline \multirow{3}{*}{$\begin{array}{l}\text { Totals } \\
\text { across } \\
\text { Strata }\end{array}$} & Open & 799 & 769 & 740 & 724 & 693 & 664 & 635 & \\
\hline & Closed & & 30 & 29 & 16 & 33 & 29 & 29 & 166 \\
\hline & $\%$ Closed & & $3.9 \%$ & $3.9 \%$ & $2.2 \%$ & $4.8 \%$ & $4.4 \%$ & $4.6 \%$ & $20.78 \%$ \\
\hline $\begin{array}{c}\text { Min } \\
\text { Wage } \\
\text { Key (Per } \\
\text { Hour) }\end{array}$ & $\$ 9.00$ & & .00 & $\$ 10.50$ & $\$ 11$ & & 12.00 & $\$ 13.25$ & $\$ 14.25$ \\
\hline
\end{tabular}

Note: Only restaurants first observed in Round 1 are included in the closure analysis. 


\section{Appendix B: Price Changes by Border Distance and Loess Regressions}

These plots repeat the analysis showed in Figure 6 but using Loess regression. We plot the difference in food item prices between rounds 1 and 7 against the distance of that items' restaurant to the wage border by census tract median household income. We fit separate rolling average lines to the points on either side of the wage border using Loess regressions with a 100\% search distance.

Figure B1: Average Price Changes by Distance to the Wage Border with Loess Fit Lines

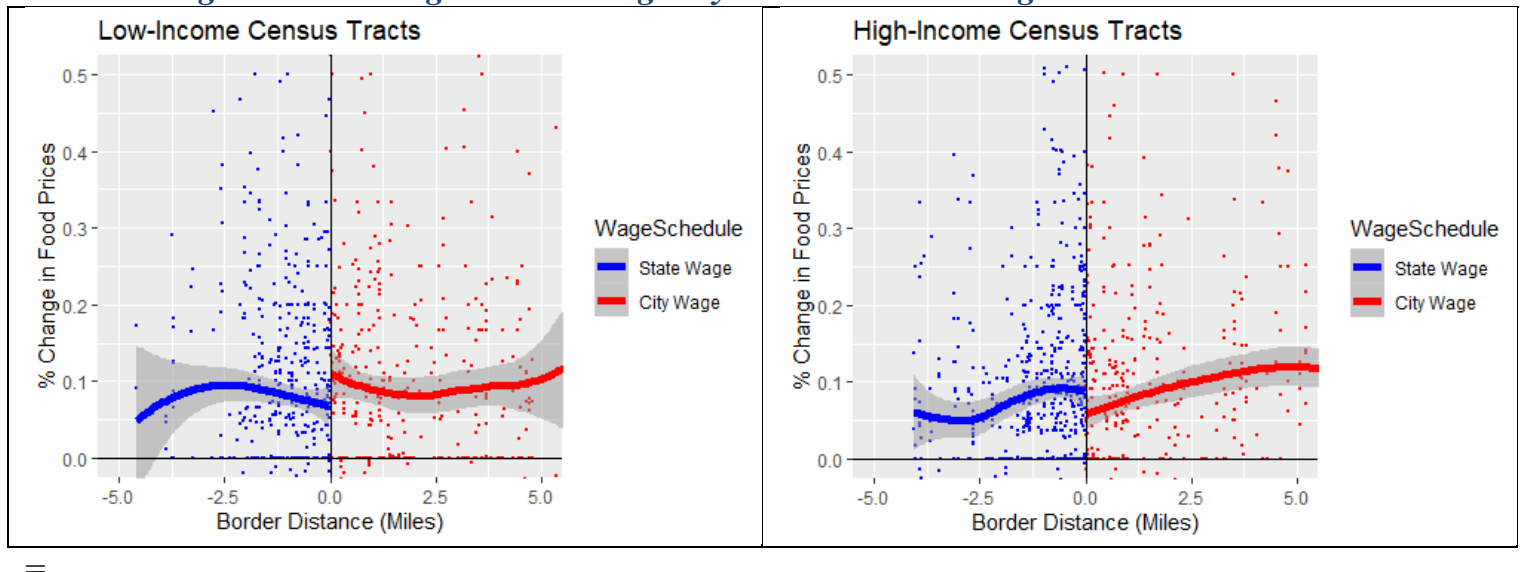

$=$

For high-income census tracts at the border the long-difference price change is estimated to be .19 with a standard error of .016 for the State Wage Border and .12 or the City Wage Border region, more than two standard errors distant. For low-income census tracts the price change is estimated to be .17 with a standard deviation of .017 for the State Wage Border region, virtually the same as the highincome census tracts, and .18 for the City Wage Border region, more than two standard deviations distant. Therefore, the conclusions for the infinite polynomial fit lines shown in Figure 9 are robust to the use of Loess regressions for the analysis. 